\title{
Jurisdictional Competition and the Evolution of the Common Law
}

\author{
Daniel Klerman $\dagger$
}

This Article explores the role that jurisdictional competition played in the development of the common law. For most of English legal history, there were several courts with overlapping jurisdiction. In addition, judges received fees for each case. As a result, judges had an incentive to hear more cases. The central argument of this Article is that, since plaintiffs chose the forum, judges and their courts competed by making the law more favorable to plaintiffs. Courts expanded their jurisdictions to give plaintiffs more choices; they made their procedures cheaper, swifter, and more effective; and they developed legal doctrines that made it difficult for defendants to prevail. Of course, jurisdictional competition was not without constraints, most importantly Parliament and Chancery. This Article tries to show how important features of the common law, including the structure of contract law, can be explained as the result of competition among courts and the constraints on that competition.

$\dagger$ Professor of Law and History, USC Law School; JD, The University of Chicago; PhD (History), The University of Chicago. The author thanks Lisa Bernstein, Alexia Brunet, Hamilton Bryson, John Coates, David Crook, Barry Cushman, John de Figueiredo, Richard Epstein, Thomas Gallanis, Nicholas Georgakopolous, Joshua Getzler, Victor Goldberg, Jeffrey Gordon, Gillian Hadfield, Philip Hamburger, Richard Helmholz, Scott Hemphill, Ehud Kamar, Louis Kaplow, Peter Karsten, Avery Katz, Timur Kuran, Gregory LaBlanc, John Langbein, Douglas Lichtman, James Lindgren, Bentley MacLeod, Edward McCaffery, Mathew McCubbins, Edward Morrison, James Oldham, Eric Posner, Richard Posner, Claire Priest, Eric Rasmusen, Jonathan Rose, Alan Schwartz, Robert Sitkoff, Matthew Spitzer, Eric Talley, Mark Weinstein, James Whitman, Abraham Wickelgren, Steven Yeazell, Todd Zywicki, and participants in the University of Chicago, Columbia, Harvard, and Northwestern Law \& Economics Workshops, Chapman, University of Colorado Boulder, George Mason, USC, and University of Virginia Law School Faculty Workshops, University of Illinois Urbana-Champaign and Washington \& Lee Legal History Workshops, UCLA Economic History Workshop, USC Development Seminar, NBER Law \& Economics Summer Institute, 17th British Legal History and Exeter International Legal History Conferences, and American Law \& Economics Association 2006 and Australia \& New Zealand Legal History Society 2002 annual meetings for comments and suggestions. The author is grateful for financial support from USC Law School and an Advancing Scholarship in the Humanities and Social Sciences grant from the USC Provost's office. Early versions of this paper were published under the title Jurisdictional Competition and the Evolution of the Common Law: A Hypothesis in 8 Austl J Legal Hist 1 (2004) and in Anthony Musson, ed, Boundaries of Law: Geography, Gender and Jurisdiction in Medieval and Early Modern Europe 149-68 (Ashgate 2005). This Article is (C) 2007 by Daniel Klerman. 
Starting in 1799 , statutes took fees away from the judges. The hypothesis that competition induced a pro-plaintiff bias is tested by quantitative analysis of judicial decisionmaking before and after those statutes.

The fees of court seem originally to have been the principal support of the different courts of justice in England. Each court endeavoured to draw to itself as much business as it could. . . . [E]ach court endeavoured, by superior dispatch and impartiality, to draw to itself as many causes as it could. The present admirable constitution of the courts of justice in England was, perhaps, originally in a great measure, formed by this emulation, which anciently took place between their respective judges; each judge endeavoring to give, in his own court, the speediest and most effectual remedy, which the law would admit, for every sort of injustice.

Imagine a system in which there are several courts, public or private, with overlapping jurisdictions, and the judges are paid out of litigant fees and therefore have a direct pecuniary interest in attracting business .... [I]t might seem that competition would lead to an optimal set of substantive rules and procedural safeguards. But this is incorrect. The competition would be for plaintiffs, since it is the plaintiff who determines the choice among courts.

Left unexplained ... is the actual pattern of competition in the English courts during the centuries when the judges were paid out of litigant fees and plaintiffs frequently had a choice among competing courts. There is evidence of competition among the courts for plaintiffs through substantive and procedural innovation, but none (of which we are aware) of the kind of blatant plaintiff favoritism that our economic analysis predicts would emerge in such a competitive setting. Why it did not emerge (assuming it has not simply been overlooked by legal historians) presents an interesting question for further research.

\footnotetext{
1 Adam Smith, 2 An Inquiry into the Nature and Causes of the Wealth of Nations 241-42 (Chicago 1976) (Edwin Cannan, ed).

2 William M. Landes and Richard A. Posner, Adjudication as a Private Good, $8 \mathrm{~J}$ Legal Stud 235, 254-55 (1979). The author thanks Todd Zywicki for calling attention to this analysis of competition.
} 
Historians explain the development of the common law in many ways. Some emphasize the internal logic of legal concepts, ${ }^{3}$ while others focus on external factors, such as political, social, or economic conditions. "A few point to the influence of philosophy' or other legal systems. ${ }^{6}$ For many, the institutional structure of the legal system is of paramount importance, whether it be the role of juries, 'the changing dynamics of pleading and post-trial motions, or innovation by lawyers in the service of their clients. ${ }^{8}$ Among the institutional factors which influenced legal development, many historians point to competition among courts as an agent of legal change.' While references to jurisdictional competition are common in the literature, no one has rigorously analyzed the implications of competition for the evolution of the common law. That is the goal of this Article.

The main argument of this Article is that since plaintiffs chose the forum, courts competed by making the law more favorable to plaintiffs. Courts expanded their jurisdictions to give plaintiffs more choices, made their procedures cheaper, swifter and more effective,

3 See generally, for example, Peter Karsten, Heart versus Head: Judge-Made Law in Nineteenth-Century America (North Carolina 1997).

4 See generally, for example, Morton J. Horwitz, The Transformation of American Law, 1780-1860 (Harvard 1977).

5 See generally, for example, James Gordley, The Philosophical Origins of Modern Contract Doctrine (Clarendon 1991).

6 See, for example, R.H. Helmholz, Canon Law and the Law of England 263-89 (Hambledon 1987).

7 See, for example, Daniel Klerman, Was the Jury Ever Self-Informing?, 77 S Cal L Rev 123, 124 (2003) ("The idea of the self-informing jury has provided a powerful explanation for many legal developments."); John H. Langbein, Historical Foundations of the Law of Evidence: A View from the Ryder Sources, 96 Colum L Rev 1168, 1172 (1996) (arguing that the law of evidence developed, in large part, because of the jury system).

8 See generally S.F.C. Milsom, Historical Foundations of the Common Law (Butterworths 2d ed 1981).

9 See, for example, Todd Zywicki, The Rise and Fall of Efficiency in the Common Law: A Supply-Side Analysis, $97 \mathrm{Nw} \mathrm{U} \mathrm{L} \mathrm{Rev} \mathrm{1551,} \mathrm{1581-621} \mathrm{(2003)} \mathrm{(arguing} \mathrm{that} \mathrm{competition} \mathrm{led} \mathrm{to}$ innovation and gave judges incentives to provide efficient legal rules); J.H. Baker, An Introduction to English Legal History 40-47 (Butterworths 4th ed 2002) (describing "the appearance of an internecine struggle for business between the common-law courts" in the later sixteenth century); Ron Harris, Industrializing English Law: Entrepreneurship and Business Organization, 1720-1844 25, 25-26 (Cambridge 2000) (noting that the common law courts "competed with each other over litigants"); Bruce Kercher, An Unruly Child: A History of Law in Australia xvii (Allen \& Unwin 1995) ("[I]n the competition for fees each [court] sought to expand its jurisdiction to cover the most lucrative business.”); A.H. Manchester, A Modern Legal History of England and Wales 1750-1950, 129 (Butterworths 1980) (noting "fierce competition" between the Court of King's Bench, the Court of Common Pleas, and the Court of Exchequer); Adam Smith, Lectures on Jurisprudence 281-82, 423-25 (Oxford 1978) (R.L. Meek, D.D. Raphael, and P.G. Stein, eds) (noting that various English courts "endeavoured ... to encourage prosecutors to come before them"); Smith, 2 Wealth of Nations at 241-42 (cited in note 1) (arguing that competition between English courts enhanced the speed and impartiality of justice). The author thanks Todd Zywicki for providing the citations to Adam Smith. 
and developed legal doctrines that made it difficult for defendants to prevail. This Article will attempt to show that this dynamicjurisdictional competition-was an important engine of legal change in England from the twelfth century to the nineteenth.

Of course, jurisdictional competition was not without constraints. If it were, the law might have become outrageously pro-plaintiff. That it did not is a testament to the existence of constraints, chief among them Parliament and Chancery. ${ }^{10}$

Jurisdictional competition presumes that courts want to hear more cases. It is less than obvious that modern judges share this desire. They might prefer fewer but more interesting cases, or more leisure." Until the nineteenth century, however, English judges had strong incentives to hear cases. In addition to the power and prestige that accrue to judges in all ages, English judges derived much of their income from fees paid by litigants. The more litigants patronizing a particular court, the richer its judges. ${ }^{12}$

Beginning in 1799 , statutory reforms took fees away from the judges. By comparing judicial decisionmaking before and after passage of these statutes, it is possible to test empirically whether fee competition affected the development of the law. Statistical analysis of three newly created datasets provides results that are consistent with the hypothesis that competition resulted in a pro-plaintiff bias.

Many lawyers will find the assertion of a pro-plaintiff bias in the common law absurd. Most law students are taught that the common law was pro-defendant. It is a commonplace of the first-year curriculum that doctrines such as privity of contract and the fellow-servant rule made it nearly impossible for plaintiffs to prevail. This view of the common law overlooks one crucial fact. These pro-defendant doctrines were developed in the nineteenth century, after statutory reforms had taken fees away from the judges and thus dampened competition among courts. ${ }^{13}$

Some readers will note similarities between the thesis of this Article and contemporary American debates over corporate law. ${ }^{14}$ Just as

10 See Part II.

11 See Richard A. Posner, Overcoming Law 117-23 (Harvard 1995) (discussing the "leisure preference in the judicial utility function").

12 See Part II.B.

13 See Part IV.

14 See, for example, Roberta Romano, The Genius of American Corporate Law 14-24 (AEI 1993); Lucian Arye Bebchuk, Federalism and the Corporation: The Desirable Limits on State Competition in Corporate Law, 105 Harv L Rev 1435, 1438 (1992); Frank H. Easterbrook and Daniel R. Fischel, The Economic Structure of Corporate Law 212-27 (Harvard 1991). But see Marcel Kahan and Ehud Kamar, The Myth of State Competition in Corporate Law, 55 Stan L Rev 679, 684 (2002). 
state revenue from incorporation fees may encourage states to mold corporate law to attract more corporations, this Article suggests that revenue from court fees encouraged English courts to mold the common law to attract more cases. Some scholars argue that competition for corporate chartering leads to efficient corporate law because managers, who choose the place of incorporation, have incentives to maximize firm value. ${ }^{15}$ In contrast, there is no reason to believe that competition among courts should have led to efficient law because plaintiffs, who chose the forum, had no incentive to prefer efficient law. Rather, plaintiffs preferred law that granted them higher recoveries, more often, more swiftly, and at lesser expense. Although Parliament and Chancery provided checks against excessively pro-plaintiff law, they were unlikely to generate efficient law. Chancery had an incentive to produce excessively pro-defendant law, and, to the extent that legislation (or the threat of it) provided a key constraint on competition between courts, common law is unlikely to have been more efficient than statutory law. ${ }^{16}$

Although this Article argues that jurisdictional competition is an important and underappreciated factor in legal development, it certainly does not argue that competition is the sole factor. As the work of numerous historians has demonstrated, doctrinal, institutional, philosophical, economic, and other explanations have substantial power."

Part I surveys the literature on the effect of jurisdictional competition on the development of English law. Part II describes the institutional background and presents some examples of the pro-plaintiff bias. Part III uses game theory and positive political theory to analyze the effects of jurisdictional competition more rigorously and to generate empirically testable predictions. Part IV describes and presents the results of three tests of the predictions generated in the previous part. Part V discusses some additional related issues.

15 Romano, The Genius of American Corporate Law at 148 (cited in note 14) ("The best available evidence indicates that, for the most part, the race is for the top and not the bottom in the production of corporation laws."); Easterbrook and Fischel, Economic Structure of Corporate Law at 214 (cited in note 14) ("As a matter of theory, the 'race for the bottom' cannot exist.").

16 The view that the common law is efficient and that statutes are less so is associated with Richard Posner. His view, however, is based largely on nineteenth century doctrine. See Richard A. Posner, Economic Analysis of Law 256 (Aspen 7th ed 2007). There is therefore no necessary contradiction between Posner's view and this Article's thesis of a pro-plaintiff bias before 1800 .

17 See generally Baker, Introduction to English Legal History (cited in note 9); Harris, Industrializing English Law (cited in note 9); Karsten, Heart versus Head (cited in note 3); Langbein, 96 Colum L Rev 1168 (cited in note 7); Gordley, Philosophical Origins of Modern Contract Doctrine (cited in note 5); Helmholz, Canon Law and the Law of England (cited in note 6); Milsom, Historical Foundations of the Common Law (cited in note 8); Manchester, Modern Legal History of England and Wales (cited in note 9); Horwitz, Transformation of American Law, $1780-1860$ (cited in note 4 ). 


\section{LITERATURE}

Judicial fee income and jurisdictional competition are well known to historians of English law. Nevertheless, they have never been analyzed in depth. The dominant position is probably that jurisdictional competition produced better law. This was the opinion of Adam Smith, as evidenced by the quote at the beginning of this Article. ${ }^{18}$ It is also the implicit position of J.H. Baker, probably the most respected living historian of English law. Consider the following passage:

It can hardly be coincidence that so much of the reform was initiated under Sir John Fyneux, who presided over the [King's Bench] from 1495 to 1525 when its fortunes were at their lowest ebb. He appointed his son in law John Rooper as chief clerk in 1498 , and the Rooper family made its fortune from the office between then and its retirement in 1616. Cynics might criticise the judges and clerks for making the court a family business; and they undoubtedly had more than a professional interest in the success of the procedures under their control. But they had no monopoly, and they thrived only by satisfying litigants and the profession at large."

First, it should be noted that this passage makes no general claims about jurisdictional competition or its effects, but rather, as is common for historians, analyzes a single court in a single period. Baker characterizes the changes wrought by Judge Fyneux and chief clerk Rooper as satisfying "litigants" generally, rather than plaintiffs specifically. This overlooks the crucial fact that it was the plaintiff who chose the court. It thus misses the insight that frequent invocation of a new legal doctrine or procedure indicates that it satisfied plaintiffs and their lawyers, not "litigants and the profession at large." Baker seems to suggest that the innovations introduced around 1500 were salutary, because the legal market was competitive (King's Bench "had no monopoly") and because the innovations introduced by Fyneux and Rooper resulted in "satisfied" customers ("litigants and the profession at large"). As through the operation of Adam Smith's "invisible hand," he seems to imply that the private interests of Fyneux and Rooper coincided with the public interest of litigants and lawyers. ${ }^{20}$

18 Smith, 2 Wealth of Nations at 241-42 (cited in note 1). See also Smith, Lectures on Jurisprudence at 281-82, 423-25 (cited in note 9).

19 Baker, Introduction to English Legal History at 44 (cited in note 9).

20 For another discussion in a similar vein, see id at 40-41 ("The legal disputes of the later sixteenth century then took on the appearance of the internecine struggle for business between the common-law themselves. ... If the King's Bench personnel had a private stake in furthering this amplification of their jurisdiction, they were at the same time meeting strong popular de- 
Other writers, such as Jeremy Bentham and Australian historian Bruce Kercher, have suggested that competition had a negative effect because it encouraged judges to create complicated, time-consuming procedures that multiplied the opportunities for fees. ${ }^{21}$ Still other historians, most prominently A.W.B. Simpson, have scoffed at the idea that judges were influenced by competition or fee income. ${ }^{22}$

At least three scholars have suggested that competition produced a pro-plaintiff bias. Landes and Posner briefly suggested as much in 1979. The relevant sections are quoted at the beginning of this Article. In the mid-1980s, Clinton Francis published two articles on eighteenth- and nineteenth-century contract law arguing that jurisdictional competition produced a pro-creditor (and hence a pro-plaintiff) bias. ${ }^{2}$ The work of these three scholars relating to the effects of jurisdictional competition has been largely forgotten. ${ }^{24}$ Clinton Francis no longer publishes in legal history, and Landes and Posner have never returned to the issue.

\section{INSTITUTIONAL BACKGROUND AND DESCRIPTIVE EVIDENCE}

\section{A. The Court System}

For most of the last thousand years, England was home to a multiplicity of courts. The most fundamental distinction lay between royal courts and nonroyal courts. Nonroyal courts included manorial courts (run by lords for tenants on their manors), honorial courts (run by lords for their vassals), ecclesiastical courts (run by the church), and local courts (run by boroughs, hundreds, and counties). Royal courts

mands."). In other places, Baker is more careful to note that a change favored plaintiffs. J.H. Baker, ed, 2 The Reports of Sir John Spelman 56 (Selden 1977) ("[T] he willingness of a court to approve new ideas which would tempt plaintiffs must have been related to the fortunes of that court."). On the other hand, even here Baker is not making a general statement about the effect of competition.

21 See Jeremy Bentham, Rational of Judicial Evidence, in John Bowring, ed, 6 The Works of Jeremy Bentham 199-201 (Russell \& Russell 1962); Kercher, An Unruly Child at xviii (cited in note 9) (observing that procedural intricacies were at least partially attributable to intercourt competition).

22 See A.W.B. Simpson, A History of the Common Law of Contract: The Rise of the Action of Assumpsit 292-95 (Oxford 1975).

23 Clinton W. Francis, Practice, Strategy, and Institution: Debt Collection in the English Common-Law Courts, 1740-1840, 80 Nw U L Rev 807, 847-52 (1986); Clinton W. Francis, The Structure of Judicial Administration and the Development of Contract Law in SeventeenthCentury England, 83 Colum L Rev 35, 43-45 (1983). See also generally Vincy Fon \& Francesco Parisi, Litigation and the Evolution of Legal Remedies, 116 Pub Choice 419 (2003) (predicting a pro-plaintiff bias as a result of plaintiff choice of forum).

24 A Westlaw search revealed only one reference to Landes and Posner's prediction of "plaintiff favoritism." See Zywicki, $97 \mathrm{Nw}$ U L Rev at 1607-08 (cited in note 9). The reference to plaintiff favoritism occurs in a discussion that also includes discussion of a prior version of this Article. 
were divided between common law courts and non-common law courts. The three common law courts were King's Bench, Common Pleas, and Exchequer. The most important royal, non-common law court was Chancery, sometimes known as the court of equity, but there were others, including Star Chamber, Admiralty, and the Court of Requests. ${ }^{25}$

By the seventeenth century, nonroyal courts were of relatively little importance. King's Bench could stop proceedings in these courts by issuing writs of prohibition. In addition, manorial, seigniorial, and local courts were limited by their inability to try criminal cases, civil cases involving more than forty shillings, or cases involving freehold land (except pursuant to royal writ). Ecclesiastical courts had jurisdiction over internal church affairs, matrimonial disputes, and probate, but had lost or given up the right to decide contract cases. ${ }^{26}$ Because of their limited powers, this article will pay little attention to nonroyal courts.

Although the three common law courts-King's Bench, Common Pleas, and Exchequer-had distinct jurisdictions in the medieval period, by 1600 their civil jurisdictions were largely coextensive. Nearly any case involving property, contract, or tort could be brought in any of the three courts. Chancery's most important jurisdiction involved trusts and contracts. ${ }^{27}$

In nearly all cases, the plaintiff chose the court. There were only a few exceptions. Cases in nonroyal courts could sometimes be removed by the defendant into royal courts. ${ }^{28}$ In this way, the royal courts could gain cases at the expense of nonroyal courts by making the law more favorable to defendants. This pro-defendant bias does not seem to have been prominent because cases could not be removed from one royal court to another. A defendant in a common law court could, however, petition in Chancery for an injunction ordering the plaintiff not to continue his common law suit. This possibility was a major constraint on the development of excessively pro-plaintiff law. King's Bench, however, had a countervailing power through the writ of habeas corpus. Chancery enforced its decrees through imprisonment.

25 See Theodore F.T. Plucknett, A Concise History of the Common Law 83-100, 176-98 (Butterworths 5th ed 1956). County courts, city courts, and other local courts were often considered royal courts, under the theory that their jurisdiction was delegated by the king. They could also be considered common law courts. This Article focuses on the three principal common law courts mentioned in the text.

26 Baker, Introduction to English Legal History at 127-29 (cited in note 9) (observing that the ecclesiastical courts had jurisdiction "over family matters, sexual offenses, defamation, and breach of faith"). See generally R.H. Helmholz, Assumpsit and Fidei Laesio, 91 L Q Rev 460 (1975) (describing loss of ecclesiastical jurisdiction over contract cases).

27 Baker, Introduction to English Legal History at 49, 97-105.

28 See Robert C. Palmer, The County Courts of Medieval England, 1150-1350 231 (Princeton 1982) (describing the procedure by which defendant in local court could remove his case to royal court). 
King's Bench, however, could use the writ of habeas corpus to free defendants from prison. By doing so, it imposed limits on Chancery's ability to constrain it. ${ }^{29}$

Each court was free to develop its own law. The development of judge-made common law amply demonstrates this freedom. Courts defined and expanded their jurisdictions, developed new procedures, and introduced doctrinal innovations without asking permission from Parliament or any other authority. In fact, this is a defining characteristic of the common law system. Until the mid-nineteenth century, there was no system of appeals by which one set of courts could comprehensively review the decisions of others. This is important because a system of appellate review might have constrained intercourt competition by imposing uniformity. ${ }^{30}$ The only real constraints on common law rulemaking were Chancery's power to issue injunctions (discussed above), the King's and-after 1701-Parliament's power to remove judges, and the power of Parliament to pass statutes that were valid notwithstanding common law decisions to the contrary.

\section{B. Judicial Compensation}

The idea that jurisdictional competition resulted in law more favorable to plaintiffs presumes that judges had an incentive to hear more cases. Judges' incentives to hear more cases could have come from many sources. In many times and places, judges are motivated by the power and prestige that comes from the ability to decide. This motivation can be recast in a public-spirited vein: a judge who believes his own decisions to be just will want to ensure that as many cases as possible come before him. In addition, before the nineteenth century, English judges received a large fraction of their incomes from fees. Although they also received a salary, they were free to augment it by fee income. Fees were a regular part of the judicial process. At every stage of a case, litigants paid a fee. Some of these fees were paid to court staff, who thereby also acquired an incentive to augment the court's caseload, while other fees were paid directly to the judges.

29 See, for example, Courtney $v$ Glanvil, 79 Eng Rep 294, 294 (KB 1615) (granting habeas corpus to a man imprisoned for failure to perform a Chancery decree).

30 There was a limited system of appellate review through "proceedings in error" that involved King's Bench, ad hoc courts, and the House of Lords. This system was severely limited by the fact that appeals could be based only on the record (primarily the pleadings) rather than evidence produced at trial. See Part V.E for more details.

31 See Baker, Introduction to English Legal History at 41, 44 (cited in note 9); Manchester, Modern Legal History of England and Wales at 81, 129 (cited in note 9) (noting the extent to which litigant fees supplemented the salaries of judges); Daniel Duman, The Judicial Bench in England 1727-1875: The Reshaping of a Professional Elite 111-16 (Royal Historical Society 1982); Marjorie Blatcher, The Court of King's Bench 1450-1550: A Study in Self-Help 34-46,144-45, 
Even fees paid to other court officials might benefit the judges, especially the chief judge, because the chief judge usually had the authority to appoint court officials. When staff fee income was large, the chief judge could and did sell the right to be a court official and thus effectively appropriated a portion of the fees paid to judicial staff. ${ }^{32}$ In addition, a judicial officer might be a relative of the chief judge, in which case fees paid to the officer would indirectly benefit the chief judge. One famous instance of such nepotism involved Chief Judge Fyneux of the King's Bench, who appointed his son-in-law, John Rooper, chief clerk ("prothonotary") of his court. ${ }^{33}$ During the period when Fyneux and Rooper ran the King's Bench, the court introduced many procedural and substantive improvements that increased its caseload.

A 1798 Parliamentary report provides valuable insight into fees in the late eighteenth century:

TABLE 1

JUDICIAL SALARIES AND FEES, $1797^{35}$

\begin{tabular}{|c|c|c|c|c|}
\hline & Salary & Fees & $\begin{array}{r}\text { Total Judicial } \\
\text { Income }\end{array}$ & $\begin{array}{r}\text { Fees as a \% of Total } \\
\text { Judicial Income }\end{array}$ \\
\hline Chancellor & $£ 5,000$ & $£ 5,870$ & $£ 10,870$ & $54 \%$ \\
\hline Chief Justice King's Bench & 4,000 & 2,399 & 6,399 & $37 \%$ \\
\hline Puisne Judge King's Bench & 2,400 & 554 & 2,954 & $19 \%$ \\
\hline Chief Justice Common Pleas & 3,500 & 2,025 & 5,525 & $37 \%$ \\
\hline $\begin{array}{l}\text { Puisne Judges Common Pleas } \\
\text { (average) }\end{array}$ & 2,400 & 411 & 2,811 & $15 \%$ \\
\hline $\begin{array}{l}\text { Chief Baron Exchequer } \\
\text { Puisne Barons Exchequer }\end{array}$ & 3,500 & 323 & 3,823 & $8 \%$ \\
\hline (average) & 2,400 & 356 & 2,756 & $13 \%$ \\
\hline Average & 2,892 & 1,705 & 5,593 & $26 \%$ \\
\hline
\end{tabular}

151-53 (Athlone 1978) (reciting a number of litigant fees owed to various officers); An Exact Table of Fees of the Courts at Westminster (London 1760). The author thanks James Oldham for calling attention to, and providing a copy of, An Exact Table.

32 See Manchester, Modern Legal History of England and Wales at 102-04 (cited in note 9) (noting that there were several "saleable offices" in the court of King's Bench); Duman, Judicial Bench in England at 116-21 (cited in note 31) ("In some cases the offices in a judge's gift would be sold, with the proceeds going directly to the judge who controlled each office.").

33 Baker, Introduction to English Legal History at 44 (cited in note 9).

34 Id at 43-44; Blatcher, The Court of King's Bench at 145-46, 149-50 (cited in note 31).

35 All amounts rounded to the nearest pound. There were three puisne (nonchief) judges on each common law court. The figures in the table are averages of the puisnes for each court. Each puisne had the same salary, and fees varied by at most 3 percent for the puisne judges of King's Bench and Common Pleas, and at most 39 percent for puisne barons of the Exchequer. 
The Table suggests that fee income was substantial. It provided several hundred pounds of income for puisne (nonchief) judges, and several thousand pounds of income for the Chancellor and chief justices of King's Bench and Common Pleas. These sums were significant components of total judicial income. For the judges with the fattest fee income, fees composed more than a third of their total official compensation. For most of the other judges, fees provided between 10 and 20 percent of their incomes. Fee income was also large in an absolute sense. One pound in 1797 would be worth about $\$ 100$ today, so average fee income would have been over $\$ 100,000$ per year.

There are no comprehensive data on fee income before 1798 . There are some hints, however, that fees provided a greater percentage of judicial income in prior centuries.

TABLE 2

JUDICIAL SALARIES AND FEES, SIXTEENTH AND SEVENTEENTH CENTURIES

\begin{tabular}{lcrrr}
\hline & Salary & Fees & $\begin{array}{r}\text { Total Judicial } \\
\text { Income }\end{array}$ & $\begin{array}{r}\text { Fees as a \% of Total } \\
\text { Judicial Income }\end{array}$ \\
\hline $\begin{array}{c}\text { Puisne judges of King's } \\
\text { Bench and Common Pleas, }\end{array}$ & $£ 120$ & $£ 248$ & $£ 368$ & $67 \%$ \\
$\begin{array}{c}\text { 1524-1525 (average) } \\
\begin{array}{c}\text { James Whitelock, puisne } \\
\text { judge King's Bench, 1627 }\end{array}\end{array}$ & 4,000 & 2,399 & 6,399 & $37 \%$ \\
$\begin{array}{c}\text { Thomas Rockeby, puisne } \\
\text { judge King's Bench, }\end{array}$ & & & & \\
$\quad$ 1689-1698 (10 year average) & 2,400 & 554 & 2,954 & $19 \%$
\end{tabular}

Sources: Edward Foss, 5 The Judges of England 99 (London 1948-1964); William Holdsworth, 1 A History of English Law 254-55 (Methuen 7th ed 1956); Edward Foss, 7 The Judges of England 298-99 (London 1948-1964).

These figures are probably much less reliable than those presented above, but they do suggest that fees were a substantially larger component of income in the sixteenth and seventeenth centuries.

\section{Examples of the Pro-Plaintiff Bias}

That the common law exhibits a pro-plaintiff bias is an empirical proposition. Part IV discusses some strategies for testing this proposition more rigorously and presents some encouraging results. This Sec-

36 Robert Twigger, Inflation: the Value of the Pound 1750-1998 (Research Paper 99/20) (House of Commons Library 1999), online at http:/www.parliament.uk/commons/lib/research /rp99/rp99-020.pdf (visited Sept 3, 2007). 
tion provides some examples, which, it is hoped, provide some concreteness to the quantitative tests.

Contract disputes were the most common type of cases in early modern England, ${ }^{37}$ but the defendant had practically no defenses at common law. Duress was limited to situations where the defendant had been imprisoned or threatened with serious bodily injury at the time the contract was entered into. ${ }^{38}$ Fraud was limited to forgery of a written instrument, tampering with a written instrument, or misreading a written instrument to an illiterate defendant. ${ }^{39}$ The only other defense was incapacity, usually that the contracting party was underage or insane. ${ }^{40}$ Beyond these, there were no defenses. Mistake, for example, was no defense, whether unilateral or mutual." Nor was unconscionability. ${ }^{42}$ Penalty clauses were fully enforceable. ${ }^{43}$ If a debtor repaid a loan but forgot to have the sealed bond canceled or to get a written receipt, prior repayment was no defense, so the creditor could procure double satisfaction. ${ }^{44}$ The paucity of contract defenses made the law very favorable to plaintiffs.

This pro-plaintiff bias was partially checked by Parliament. For example, statutes in 1697 and 1705 greatly constrained creditors' ability to enforce penalty clauses. ${ }^{45}$ The second of these statutes also

\footnotetext{
37 See Baker, Introduction to English Legal History at 67-68 (cited in note 9).

38. See D.J. Ibbetson, A Historical Introduction to the Law of Obligations 71-72, 208, 252 (Oxford 1999).

39 See Baker, Introduction to English Legal History at 324 (cited in note 9); Ibbetson, Law of Obligations at 20,72 (cited in note 38 ).

40 See Ibbetson, Law of Obligations at 71, 208 (cited in note 38) ("Neither an infant nor a lunatic could act voluntarily.").

41 Baker, Introduction to English Legal History at 350-51 (cited in note 9) ("Nothing was yet heard [in 1800] in the common-law courts of offer and acceptance, mistake, or principles of remoteness of damage."); Ibbetson, Law of Obligations at 72, 226 (cited in note 38) (describing slow recognition of the defense of mistake).

42 Ibbetson, Law of Obligations at 144, 252 (cited in note 38) ("It was none of the court's business to determine the fairness of the transaction.").

43 Id at 29, 150 (noting that common law courts enforced penalty clauses until the turn of the eighteenth-century, when two statutes forbade them to do so). This may surprise some modern scholars who generally assume that nonenforcement of penalty clauses was part of the common law. Nevertheless, it should be noted that Chancery and English statutory law were the source of the rule against penalty clauses. See text accompanying note 45-47. Chancery decisions and early statutes, however, are sometimes considered part of the common law, which may explain the confusion.

44 Baker, Introduction to English Legal History at 324-25 (cited in note 9) ("[A]n obligor might be forced to pay twice on the same bond ... [as] it was his own folly not to have ... obtained an acquittance under seal."); Ibbetson, Law of Obligations at 21 (cited in note 38) (noting that a debtor could not plead that the obligation had been paid).

45 See Statute of $4 \& 5$ Anne ch $3, \S \S 12-13$ (1705) (allowing debtors to discharge debts evidenced by bond by bringing into court monies sufficient to pay the principal, interest, and costs expended in the lawsuit); Statute of 8 \& 9 Will III ch 11, \& 8 (1697) (discharging obligations where breaching party paid damages, court costs, and certain other "reasonable Charges and
} 
barred recovery when the debtor had paid but failed to procure a written receipt of payment.

Chancery also provided an important constraint. As a separate court, Chancery had the power to issue injunctions against ongoing proceedings in the common law courts. This power provided an important check on the pro-plaintiff bias in the common law. Through its injunction power, Chancery could, in effect, transform a defendant in a common law court into a plaintiff in Chancery. As a result, in order to attract injunction business, Chancery had an incentive to develop law favorable to defendants in common law actions. For example, if a debtor who had repaid a written loan but failed to procure a written receipt or cancellation of the loan instrument was sued in Common Pleas, that court was likely to rule against him. Nevertheless, the debtor could petition Chancery for an injunction. ${ }^{46}$ Chancery had an incentive to grant the injunction, because those who petitioned for an injunction would, like any claimant, pay a fee to the court. In addition, once the creditor was sued in Chancery, he too would have to pay fees. A Chancery injunction would prohibit the creditor from proceeding in Common Pleas to collect the debt. Over time, Chancery developed a series of legal doctrines governing the issuance of such injunctions. These doctrines form the basis of the contract defenses we know today, including mistake, unconscionability, and the rule against penalties. ${ }^{47}$

Another example of the pro-plaintiff bias relates to oral contracts. In the Middle Ages, Common Pleas had a monopoly on debt cases and decided oral debt cases by a pro-defendant method called "compurgation," in which the debtor was released from liability if he could find eleven people who would swear that he (the debtor) was in the right. Starting in the fifteenth century, King's Bench began to compete for cases involving oral promises by allowing such cases to go to a jury rather than compurgation using indebitatus assumpsit writs. Juries, however, were perceived as excessively pro-plaintiff, because they were willing to hold defendants liable on trumped-up evidence. In response, Parliament passed the Statute of Frauds (1677), ${ }^{48}$ which made most important categories of unwritten contracts unenforceable.

Expenses"); Baker, Introduction to English Legal History at 325-26 (cited in note 9) (describing statutes requiring a creditor to only pay what was owed in equity, not the full amount of the penalty clause); Ibbetson, Law of Obligations at 150, 214 (cited in note 38) (describing these statutes as well as their effects).

46 Baker, Introduction to English Legal History at 102-03, 106 (cited in note 9).

47 Ibbetson, Law of Obligations at 72-73, 150, 208-10, 213-14, 226-27 (cited in note 38).

48 Statute of 29 Car II ch 3 (1677). See also Baker, Introduction to English Legal History at 349-50 (cited in note 9); Ibbetson, Law of Obligations at 203 (cited in note 38); Philip Hamburger, The Conveyancing Purposes of the Statute of Frauds, 27 Am J Legal Hist 354, 372 (1983); Simpson, A History of the Common Law of Contract at 298-99 (cited in note 22). 
Other examples could easily be provided, including the medieval expansion of royal jurisdiction over tort and contract, the substitution of jury trial for wager of law in a wide array of actions, early modern pleading, the writ of ejectment, and the creation of liability for unjust enrichment.

\section{THEORY}

This Part attempts to analyze more rigorously the implications of jurisdictional competition using game theory and positive political theory. It first analyzes competition between courts under the assumption that competition was unconstrained by Parliament or other institutions. It then models the effects of Parliamentary constraint.

\section{A. Jurisdictional Competition}

Part III.A attempts to justify a relatively simple proposition: when plaintiffs choose the forum and judges receive fees, jurisdictional competition gives judges incentives to make pro-plaintiff law. This proposition leads to the following testable prediction:

Prediction 1. When judicial fees are taken away, the common law will become less pro-plaintiff.

Although to some this idea seems so obvious that it requires no extended discussion, the issue is actually complex, because a proplaintiff rule might lead to less litigation than a more pro-defendant rule. The pro-plaintiff rule might lead to less litigation for at least two reasons: it might give potential defendants greater incentives to avoid liability-creating activities, thus reducing the number of disputes, or the pro-plaintiff rule might be so clear that it induces more cases to settle out of court.

Part III.A proceeds in two subsections. First, it presents two numerical examples to illustrate the pro-plaintiff bias. Then, it enriches the discussion by considering the choice between rules and standards. The Appendix presents a formal model that generalizes the examples and justifies the prediction, first assuming that judges care only about fee income and then considering the implications of judicial preferences about the content of legal rules.

1. Two examples illustrating the pro-plaintiff bias.

Consider first a very simple situation. Two courts, King's Bench (KB) and Common Pleas (CP), care only about their caseloads (and 
attendant fee income) ${ }^{49}$ and have a choice between two rules, one proplaintiff (pro- $\pi$ ) and the other pro-defendant (pro- $\Delta$ ). The rules need not be pro-plaintiff or pro-defendant in any absolute sense, but only relative to each other. The pro-plaintiff or pro-defendant character of each rule is judged at the time the plaintiff files suit. The pro-plaintiff rule is the one which gives the plaintiff a higher expected recovery. Such a rule may not, of course, favor plaintiffs ex ante-at the time the parties are contracting or at the time they are choosing precautions that might avoid the tort-because the pro-plaintiff rule may adversely affect contractual terms or other pre-litigation behavior. Because of the way the pro-plaintiff rule is defined, if one court has chosen the pro-plaintiff rule and the other court has chosen the prodefendant rule, the plaintiff will always choose the court which has chosen the pro-plaintiff rule. If both courts have chosen the same rule (whether it is the pro-plaintiff rule or the pro-defendant rule), plaintiffs are assumed to be indifferent and to choose randomly between the two courts. Because both parties can anticipate that the plaintiff will, if possible, file suit in a court that has chosen the pro-plaintiff rule, they can anticipate that the pro-plaintiff rule will apply to any dispute that arises, as long as at least one court has chosen that rule. On the other hand, if both courts have chosen the pro-defendant rule, parties will anticipate that that rule will apply to any dispute. For the purposes of this first example, it is assumed that the pro-plaintiff rule leads to more litigation. If at least one court has chosen the proplaintiff rule, the total caseload is one hundred cases. If both courts have chosen the pro-defendant rule, the total caseload is fifty cases. Plaintiffs are assumed to be fully informed about the law. This is plausible, because they were nearly always represented by counsel. Courts are assumed to be fully informed about each others' decisions, which is sensible, because nearly all decisions were made publicly. For simplicity, it will be assumed that King's Bench has the first opportunity to choose the rule. That is, it receives the first case which presents an opportunity to decide the applicable law. Nothing changes if the order were reversed and Common Pleas chose first. The resulting strategic situation is depicted in Figure 1.

49 This assumption is clearly false and is relaxed in the formal model in the Appendix. Nonetheless, this assumption clarifies the mechanism leading to the pro-plaintiff bias which operates in a similar way even when judicial preferences and ideology are taken into account. 
FIGURE 1

JURISDICTIONAL COMPETITION WHERE

PRO-PLAINTIFF RULE INCREASES CASELOAD

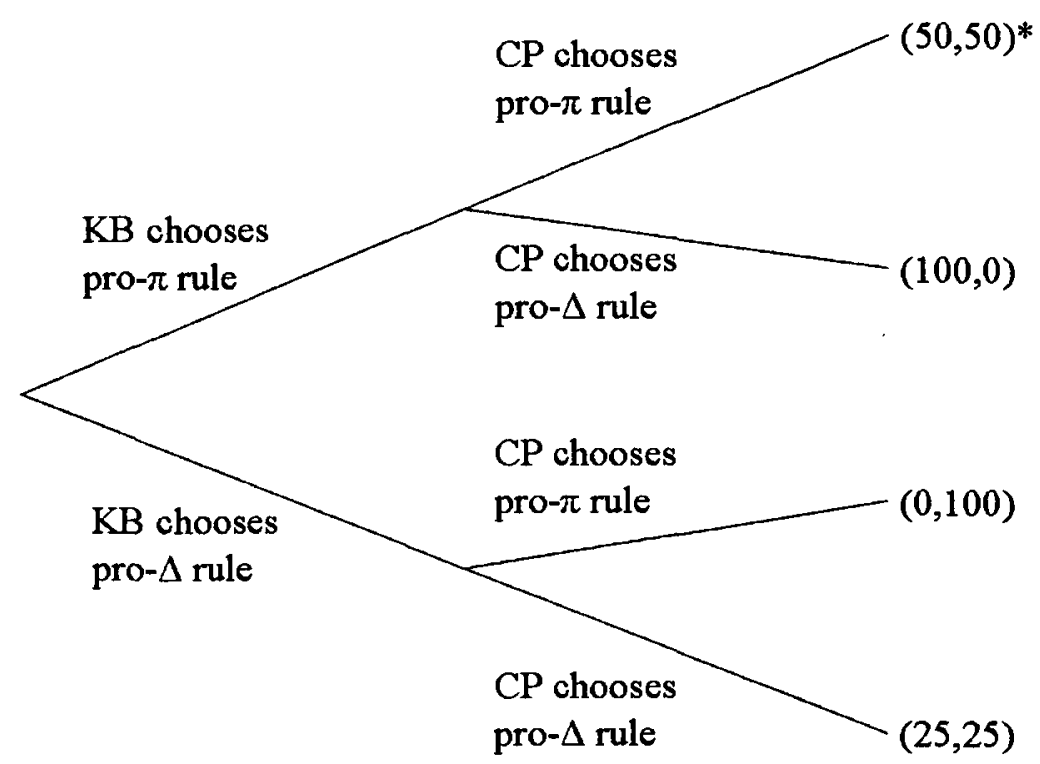

First, note the payoffs. If at least one court has chosen the proplaintiff (pro- $\pi$ ) rule, the total caseload is one hundred. If both courts have chosen that rule, then plaintiffs randomize between the two courts and each court receives fifty cases. On the other hand, if one court has chosen the pro-plaintiff (pro- $\pi$ ) rule and the other has chosen the pro-defendant (pro- $\Delta$ ) rule, the court that has chosen the proplaintiff rule receives all one hundred cases. If both courts have chosen the pro-defendant (pro- $\Delta$ ) rule, the total caseload is only fifty cases, and since plaintiffs randomize between the two courts, each court receives only twenty-five cases.

It is apparent that in this situation both courts will choose the pro-plaintiff rule. That is the sole subgame perfect Nash equilibrium. In fact, choosing the pro-plaintiff rule is a strictly dominant strategy. If King's Bench were to choose the pro-defendant (pro- $\Delta$ ) rule, it could anticipate that Common Pleas would choose the pro-plaintiff (pro- $\pi$ ) rule, because doing so would increase Common Pleas's caseload from twenty-five to one hundred. That would leave King's Bench with zero cases, because all plaintiffs would choose to file suit in Common Pleas, which had chosen the more pro-plaintiff rule. On the other hand, if King's Bench were to choose the pro-plaintiff rule, it could anticipate 
that Common Pleas would also choose that rule, because doing so would increase Common Pleas's caseload from zero to fifty. If both courts chose the pro-plaintiff rule, they would each get fifty cases, but if King's Bench chose the pro-defendant rule it would receive zero cases. Because King's Bench would prefer to have fifty rather than zero cases, it will choose the pro-plaintiff rule.

Now consider the possibility that the pro-plaintiff rule decreases the total amount of litigation by 40 percent. Such a situation is depicted in Figure 2.

FIGURE 2

JURISDICTIONAL COMPETITION WHERE PRO-PLAINTIFF RULE DECREASES CASELOAD BY 40 PERCENT

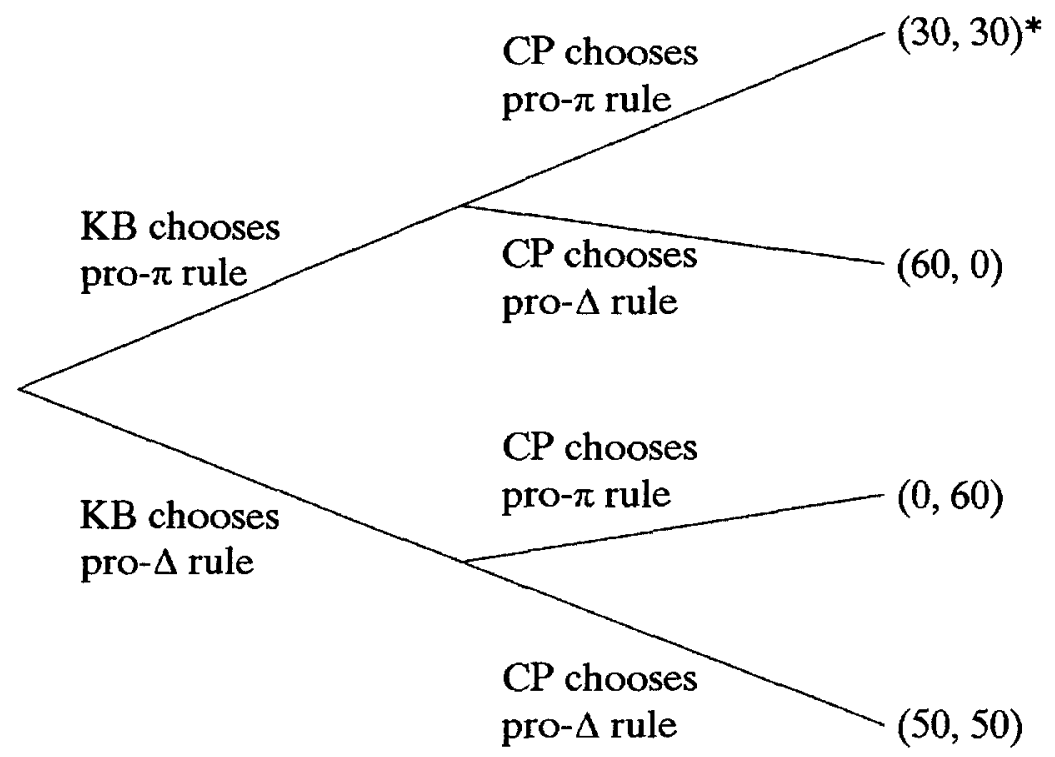

As before, note the payoffs. If both courts choose the prodefendant rule, then the total caseload is one hundred, which is split evenly between the two courts. On the other hand, if at least one court chooses the pro-plaintiff rule, the total caseload goes down by 40 percent to sixty cases. Those sixty cases all go to one court (if the courts have chosen different rules) or are divided equally between the two courts (if both have chosen the pro-plaintiff rule). This situation might represent the choice between a simple pro-plaintiff rule (which generated relatively little litigation) and a complex or ambiguous prodefendant rule or standard (which generated more litigation).

Note that in this situation the courts would maximize their joint utility by both choosing the pro-defendant rule, because doing so 
would maximize the total caseload. Nevertheless, it is in their individual self-interest for each to choose the pro-plaintiff rule, because of the strategic nature of their interaction. If King's Bench chose the prodefendant rule, it would be in the interest of Common Pleas to choose the pro-plaintiff rule, because it is better to receive all of the smaller caseload (sixty cases) than half of the bigger caseload (fifty cases). Similarly, if King's Bench chose the pro-plaintiff rule, Common Pleas will choose that rule is well, because it is better to get half the caseload (thirty cases) than nothing (zero cases). Given that King's Bench can anticipate that Common Pleas will choose the pro-plaintiff rule, it is in the interest of King's Bench to choose that rule as well, because it is better to get half of the smaller caseload (thirty cases) than nothing (zero cases).

\section{Rules versus standards.}

One might think that courts that were motivated by fee income, and thus by caseload, would prefer standards to rules because it is usually thought that standards produce more litigation than rules. Because rules are clearer than standards, it is easier for people to conform their actions to a rule and thus not violate it in the first place. In addition, because rules are clearer, even if a dispute arises, the parties are more likely to settle out of court. Nevertheless, the argument that judges motivated by fee income would prefer standards to rules is misguided because it ignores the strategic interaction between the courts. While it is true that a monopolistic court could maximize its caseload by choosing standards rather than rules, competition between courts gives each an incentive to choose clear rules.

The choice between rules and standards is partly addressed by the situation discussed in Figure 2, which analyzed the situation in which the pro-plaintiff rule reduces litigation by 40 percent. Nevertheless, that reasoning applies only if the pro-plaintiff rule reduces litigation by less than 50 percent. If the rule reduces litigation by more than 50 percent, then the argument that competition induces standards has some plausibility. Figure 3 illustrates such a situation, using strict liability as an example of a pro-plaintiff rule and negligence as an example of a pro-defendant (or less pro-plaintiff) standard. 
FIGURE 3

JURISDICTIONAL COMPETITION WHERE PRO-PLAINTIFF RULE DECREASES CASELOAD BY 60 PERCENT

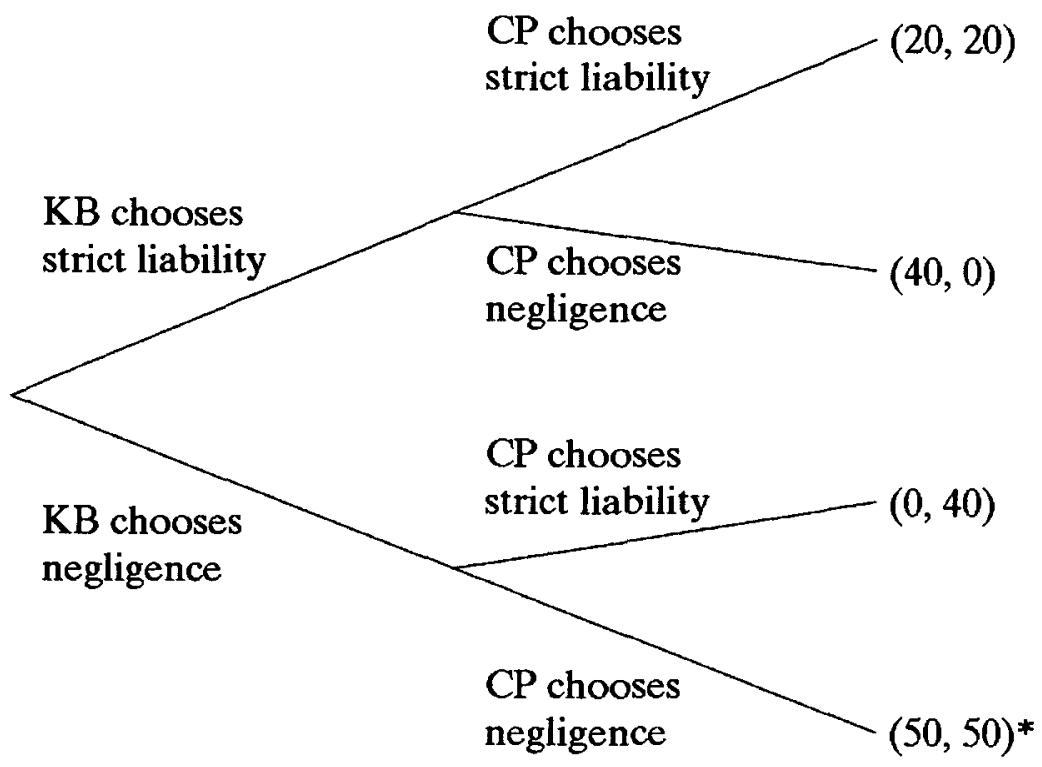

In this situation, the courts will choose negligence. That is, in the only subgame perfect Nash equilibrium, both courts choose the prodefendant standard rather than the pro-plaintiff rule. If King's Bench chooses negligence, Common Pleas will also choose negligence, because it is better to get half of the much larger caseload (fifty cases) than all of the much smaller caseload (forty cases). Because, in contrast to the situation illustrated in Figure 2, the rule reduces litigation by more than 50 percent, it is no longer in Common Pleas's interest to choose to pro-plaintiff rule (strict liability). If King's Bench chooses strict liability, it is in Common Pleas's best interest to also choose strict liability, because it is better to get half of a small caseload than no cases at all. King's Bench will therefore choose negligence, because its payoff from negligence (fifty cases) is higher than its payoff from strict liability (twenty cases).

The foregoing analysis would seem to suggest that there is merit to the argument that competitive courts might choose standards over rules, at least when the rule produces less than half as much litigation as the standard. Nevertheless, this result is an artificial consequence of forcing the courts to choose between a rule and a single standard. One of the properties of standards is that they come in many gradations. A court chooses not just between strict liability and negligence, but also 
between gross negligence, slight negligence, and ordinary negligence. To take a more modern example, in constitutional cases, courts choose between strict scrutiny, intermediate scrutiny, rational basis scrutiny, and variations thereof. Once one takes into account several possible standards, the incentive to choose the pro-plaintiff rule reemerges. This phenomenon is illustrated below in Figure 4, which takes as its starting point the choice between negligence and strict liability (illustrated in Figure 3 above), but then introduces a third possibility, slight negligence, which is intermediate between (ordinary) negligence and strict liability, both in plaintiff preference and in the amount of litigation it generates.

FIGURE 4

\section{JURISDICTIONAL COMPETITION WITH TWO POSSIBLE STANDARDS}

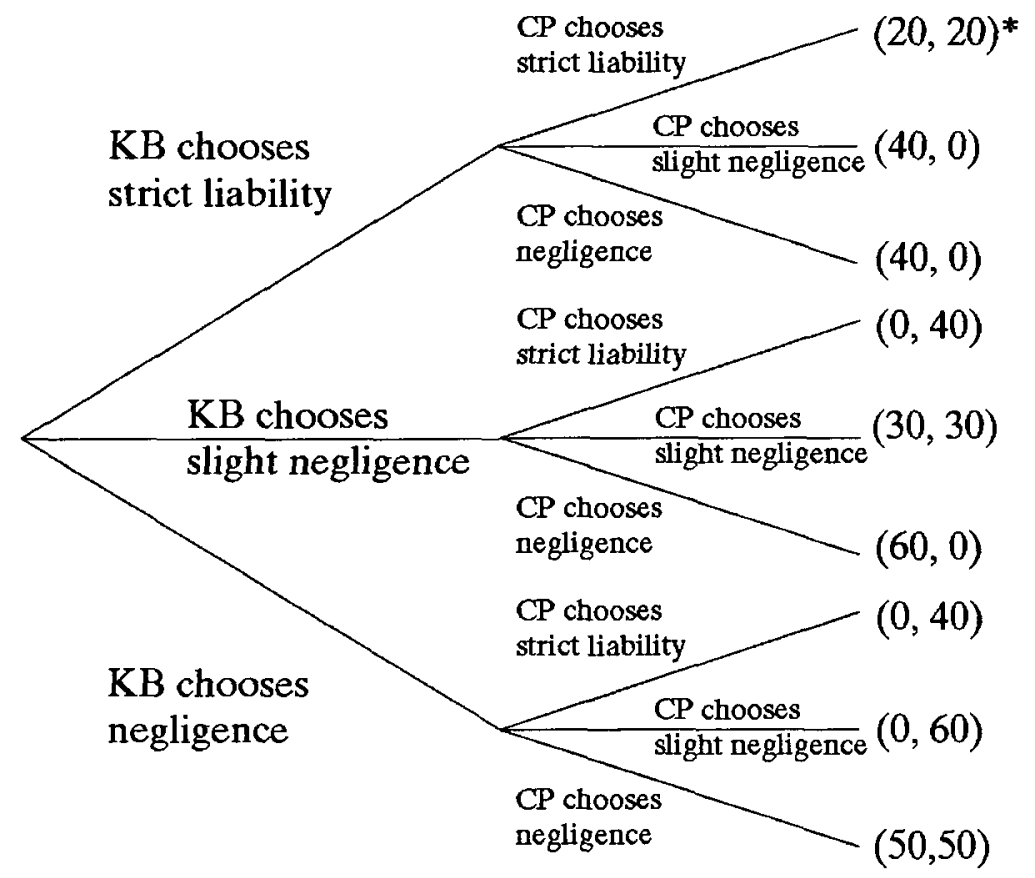

In this figure, slight negligence, like the pro-defendant rule in Figure 2, results in 40 percent fewer cases than negligence, and strict liability results in 60 percent fewer cases, as in Figure 3. Strict liability is the most pro-plaintiff, slight negligence is intermediate, and negligence is the most pro-defendant. In the sole subgame-perfect Nash equilibrium, both courts choose strict liability, the pro-plaintiff rule. If King's Bench chooses negligence, it will receive zero cases, because it can expect that Common Pleas will choose slight negligence. If King's Bench chooses slight negligence, it will receive zero cases, because it 
can anticipate that Common Pleas will choose strict liability. On the other hand, if King's Bench chooses strict liability, it will receive twenty cases, because it can anticipate that Common Pleas will also choose strict liability. Therefore, the only plausible outcome of this game is that both courts choose strict liability, the pro-plaintiff rule. The introduction of an intermediate standard, slight negligence, changes the choice (illustrated in Figure 3 ) between strict liability and negligence and disrupts the equilibrium in which both courts choose the negligence standard. The most important change is in the bottom part of Figure 4. If King's Bench chooses negligence, it can no longer count on Common Pleas doing the same. Although Common Pleas would still prefer negligence to strict liability (assuming King's Bench has chosen negligence), Common Pleas would also prefer slight negligence to (ordinary) negligence because slight negligence gives it more cases. This disrupts the negligence equilibrium, illustrated in Figure 3, which existed when Common Pleas was assumed not to have the option of choosing slight negligence.

\section{B. Legislative-Judicial Interaction}

The previous analysis assumed that judicial competition was unconstrained. Part III.B considers the fact that judicial decisions could be overturned by statute. Consider the spatial model below. ${ }^{50}$

50 For examples of spatial models, see Emerson H. Tiller and Pablo T. Spiller, Strategic Instruments: Legal Structure and Political Games in Administrative Law, $1 \mathrm{~J} \mathrm{L,} \mathrm{Econ} \mathrm{\&} \mathrm{Org} \mathrm{349,}$ 350 (1999) (using a spatial model to describe the strategic interaction between administrative agencies and legislators); William N. Eskridge, Jr., Overriding Supreme Court Statutory Interpretation Decisions, 101 Yale L J 331, 379-85 (1991) (using a spatial model to analyze the interaction between the United States Supreme Court, Congress, and the President). 


\section{A SPATIAL MODEL OF LEGISLATIVE-JUDICIAL INTERACTION}

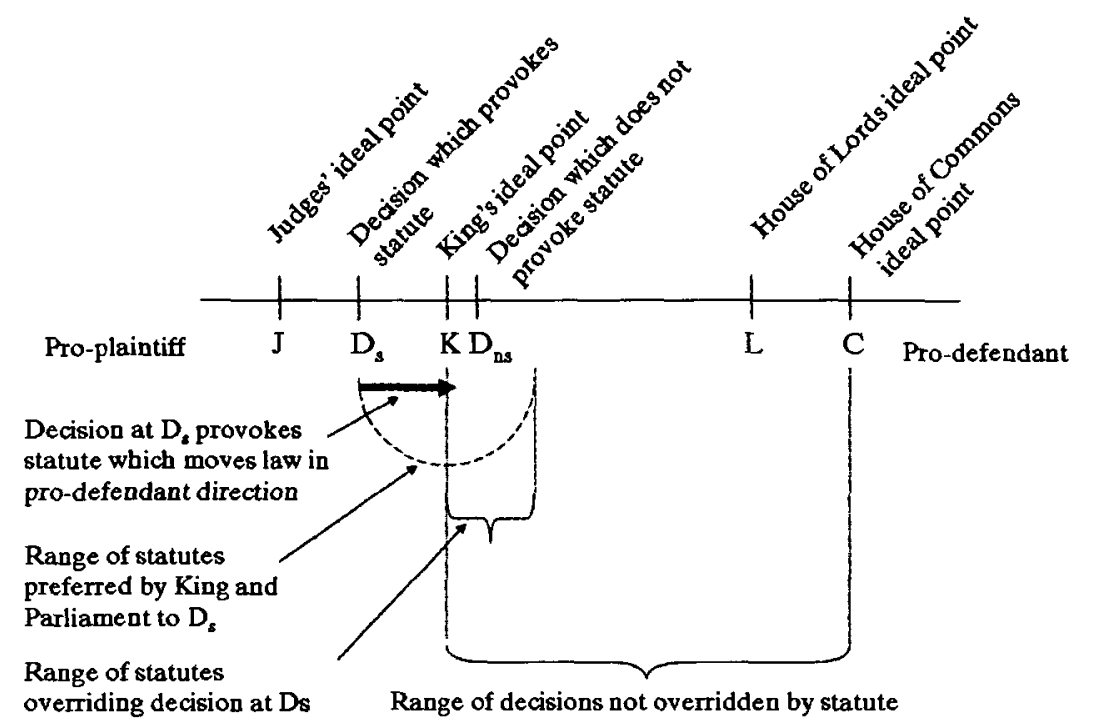

The line represents possible decisions on a particular legal issue. Decisions more favorable to the plaintiff are farther left on the line; decisions more favorable to the defendant farther right. Points $K, L$, and $C$ represent the ideal points of the King (or Queen, when sovereign), House of Lords, and House of Commons, respectively. The ideal point is the decision each would favor if it could decide the issue unilaterally. As is conventional, the preferences are assumed to be symmetric and "single peaked," which means that each prefers decisions closer to its ideal points to those farther away. The relative position of $K, L$ and $C$ is irrelevant, as long as there is some difference between at least two of them. That is, the predictions below are not dependent on the King being more pro-plaintiff than the House of Lords or Commons, or the House of Commons being more pro-defendant. And, of course, the positions, both relative and absolute, might have been different for different issues. The ideal points are likely to have been determined by the merits and politics of each issue, rather than by a desire to favor plaintiffs or defendants.

If the judges' ideal point, $J$, were always in the range between $K$ and $C$, then there would never be a statute overturning a common law decision, because a statute requires the assent of both houses of Parliament and the King, and any statute (except one which simply confirmed the court's decision) would move the law farther from the ideal point of the King or at least one house of Parliament. Since we know 
that Parliament sometimes passed statutes overturning common law decisions, it is reasonable to place $J$, the judges' ideal point, outside the range between $K$ and $C$. In theory, the judges' ideal point could be either to the left of $K$ (pro-plaintiff) or to the right of $C$ (prodefendant). Nevertheless, because judges had pro-plaintiff incentives from fees that neither Parliament nor the King had, it is reasonable to assume that $J$ was to the left of $K$, that is, that the courts were proplaintiff.

Judges, however, realized that if they made decisions at $J$, they would be overturned by Parliament. As a result, courts aimed to make decisions that were as close to their ideal point as would be tolerated. That is, they tried to make decisions that were as pro-plaintiff as possible, but still within the range that Parliament would not overturn. If judges knew the precise location of $K, L$ and $C$, they would choose a decision at $K$. Unfortunately, perfect prediction was impossible. Sometimes judges would err or would want to be sure that their decision would not be overridden, and would make a decision that was more pro-defendant than necessary, such as $D_{n s}$. Such decisions would not provoke statutory override. On the other hand, sometimes judges would err and make a decision that was more pro-plaintiff than Parliament and the King would tolerate, such as $D_{s}$. If so, both Houses of Parliament and the King would prefer a statute that moved the law at least modestly in a pro-defendant direction. So a decision at $D_{s}$ would provoke a statute that moved the law in a pro-defendant direction. The statute can further be predicted to fall within the range indicated in Figure 5, but the precise location of the statute is not important to the analysis.

Of course, it is also possible that judges would make a decision to the right of $C$, and Parliament and the King would respond with a proplaintiff decision. This, however, would be rare, as such a decision would require either an extremely large miscalculation by the judges about Parliament's and the King's ideal points or that the judges' ideal point was more pro-defendant than King and Parliament, in spite of the incentives provided by fees. This analysis suggests the following prediction:

Prediction 2. When courts receive fees and thus have an incentive to be more pro-plaintiff than legislators, most statutes will move the law in a pro-defendant direction.

If judicial incentives change and the decision of unconstrained courts moves in the pro-defendant direction (as suggested by Prediction 1), then point $J$, the judges' ideal point, will move to the right. All other things being equal, this should result in fewer pro-defendant statutes. If point $J$ moves in the range $K$ to $C$, unconstrained decisions 
will fall within the range of decisions not overturned by statute, so statutes will be uncommon. If point $J$ moves to the right of $C$, then unconstrained decisions will be more pro-defendant than Parliament and the King would tolerate, and statutes should be predominantly pro-plaintiff. This analysis suggests a third prediction:

Prediction 3. When judicial incentives to be more pro-plaintiff are lessened or removed, the proportion of statutes moving the law in a pro-plaintiff direction will increase.

It should be noted that while Prediction 2 assumes that, when judges received fee income, they preferred significantly more proplaintiff rules than legislators and the King (for example, $J$ is to the left of $K$ ), Prediction 3 does not rely on that assumption. The third prediction would be true even if fee-taking judges were more prodefendant than legislators, as long as the removal of fees moved the judges even farther in the pro-defendant direction.

One advantage of Predictions 2 and 3 over Prediction 1 is that they are not affected by selection bias in the cases that are litigated. Statutes responded to the legal rules themselves, not to litigation decisions about whether to sue or settle.

\section{Limitations of the Theory}

Although the models presented in this Part help elucidate common law decisionmaking, they obviously simplify matters and do not represent historical reality in all its complexity. It is thus important to note a few of the many limitations of these models.

1. The jurisdictional competition model assumes only two courts. For most of the relevant period, there were three competing courtsKing's Bench, Common Pleas, and Exchequer. The addition of a third court does not substantially change things. In fact, it strengthens the main results, as the pro-plaintiff equilibrium obtains in a larger set of circumstances. For example, if the pro-plaintiff rule reduces caseloads by a half to two-thirds, the pro-plaintiff rule is not an equilibrium with two courts, but it is with three.

2. The jurisdictional competition model assumes independent decisionmaking, without cooperation. This is obviously a simplification. There were relatively few premodern common law judges and they had repeated interactions, so cooperation was certainly possible. Nevertheless, the judges on different courts do not seem 
to have cooperated. The fact that judges often chose bright-line rules, which would reduce caseloads, and the fact that judges enforced arbitration agreements, ${ }^{\text {st }}$ both of which were contrary to the judges' collective interest, suggest that the assumption of noncooperative decisionmaking captures something important about the interaction between the courts. Perhaps even more strikingly, in the Middle Ages the courts had a near-perfect cooperative strategy-distinct jurisdictions-but they defected from it by expanding their jurisdictions so that, by the early modern period, nearly any important common law case could be brought in any of the three common law courts.

Nevertheless, the absence of cooperation is a bit of a puzzle. A partial explanation is to remember that in repeated games, although cooperation is a Nash equilibrium, so is defection. Another part of the explanation may be that sustaining cooperation requires that defection (that is, noncooperative decisionmaking) be identified and punished and that parties coordinate their punishment strategies, which may have been difficult in the judicial setting.

It should also be noted that even if there were collusion, much of the pro-plaintiff bias would remain. Even courts which were colluding would favor pro-plaintiff rules, as long as the proplaintiff rules increased the total caseload, which was probably true in most situations.

3. The jurisdictional competition model does not take into account litigants' incentives to settle and to frame issues strategically. This is potentially the biggest problem with the model. Some strategies for mitigating this problem are discussed in the next Part.

4. The jurisdictional competition model assumes that judges are homogeneous. Of course, they were not. Introducing heterogeneity would complicate the model without substantially altering the conclusions.

5. Prediction 2 (but not 3) assumes that unconstrained courts will make decisions that are more pro-plaintiff than Parliament. It is, of course, possible that judges had such strong pro-defendant preferences that, even with the pro-plaintiff incentives competition provided, their unconstrained decisions would still be more pro-defendant than Parliament's. Nevertheless, since judges were 
chosen by the King and were generally recruited from the same social stratum as members of the House of Commons, it seems more likely that their intrinsic preferences were roughly in accord with Parliament's and the King's, and that competition pushed them in a more pro-plaintiff direction. Of course, if the King understood the pro-plaintiff bias that competition induced, he might have deliberately chosen judges with intrinsic pro-defendant preferences, so that, taking jurisdictional competition into account, the judges would make decisions closer to the King's ideal point. This level of strategic foresight seems implausible, because there is no evidence that the King or anyone else perceived the pro-plaintiff bias that fees induced. In addition, the decision to select a judge would ordinarily have turned on many other aspects of their background and preferences (experience in the King's service, intelligence, political preferences, and so forth) so that, even if the King understood the pro-plaintiff bias and wanted to counteract it, selecting judges with intrinsic pro-defendant preferences to counteract the pro-plaintiff incentives of jurisdictional competition would have been difficult.

\section{EMPIRICAL TESTS}

The institutional structure described in Part II, which created jurisdictional competition, was radically transformed in the nineteenth century. Perhaps most importantly, statutes in 1799 and 1825 restricted royal judges to fixed salaries. ${ }^{52}$ Instead of lining the pockets of judges, fees were now allocated to the Treasury. The 1799 statute took fees away from the puisne (that is, nonchief) judges of King's Bench and Common Pleas, and from all of the Exchequer judges. ${ }^{53}$ The 1825 statute took fees away from the chief judges of King's Bench and Common Pleas. These statutes were part of a broader shift in English governance by which nearly all officials were moved from fee-based compensation to salaries. This set of reforms was not motivated by an analysis of the effect of fees on common law adjudication, but rather

52 Statute of 6 Geo IV, ch 82, §11 (1825) (taking fees away from the Chief Justice of King's Bench); ch $83 \S 10$ (1825) (taking fees away from Chief Justice of Common Pleas); Statute of 39 Geo III, ch, 90, §§ 1-3 (1799) (taking fees away from puisne judges of King's Bench and Common Pleas and all judges of Exchequer).

53 The 1799 statute took the fees away in a rather roundabout way. It gave the affected judges a salary increase, but also required them to report the amount received in fees to the Treasury every six months. The amount each judge received in fees was subtracted from his salary increase. The judges thus technically kept their fees. Nevertheless, since their fee income, which was smaller than their salary increases, was subtracted from their salaries, the net effect was the same as taking the fees away - judges no longer had any financial incentive to hear more cases. 
by general dissatisfaction with the fee system and sinecures. It is therefore reasonable to consider the statutes to be exogenous.

It seems hardly a coincidence that the pro-defendant decisions for which the common law is notorious came soon after these statutes. For example, Priestley v Fowler, ${ }^{34}$ and Hutchinson v York, Newcastle, and Berwick Railway Company, ${ }^{35}$ which established the fellow-servant rule in England, were decided in 1837 and $1850 .{ }^{56}$ These cases made it nearly impossible for an employee to prevail in tort against his employer when the negligence that caused the injury was caused by another employee (a "fellow servant") rather than directly by the employer. Similarly, Winterbottom $v$ Wright $^{57}$ was decided in 1842 . This landmark case established the privity doctrine, which barred consumers from suing the manufacturer of a defective product unless the manufacturer had sold directly to the consumer and the two were, in that way, in "privity of contract." ment of product liability law for almost a century.

Similar pro-defendant developments occurred in contract law. Early modern cases established the right of at least some third-party beneficiaries to enforce contracts for their benefit. Nevertheless, in a series of nineteenth century cases, King's Bench rejected the prior cases and held that the beneficiary could not sue, unless he or she had

54150 Eng Rep 1030 (Ex 1837).

55155 Eng Rep 150 (Ex 1850).

56 It is not argued here that prior to Priestley, employees had been able to recover and that Priestley changed the law. Rather, in Priestley the court faced a choice about what to do and decided upon a rule which led to fewer suits than a rule which held that employers were liable. In a recent analysis of the case, R.W. Kostal argues that "[t]he relevant common law was scant, ambiguous, and unevolved" and that distinguished lawyers and judges, including Baron Parke, could and did see the opposite result as justified by precedent. R.W. Kostal, Law and English Railway Capitalism 1825-1875 261, 267-68 (Clarendon 1994). Ibbetson also emphasizes that it was "judicial choices," not precedent, that led to the "invention of the 'fellow servant' rule." D.J. Ibbetson, The Tort of Negligence in the Common Law in the Nineteenth and Twentieth Centuries, in Eltjo J.H. Schrage, ed, Negligence: The Comparative Legal History of the Law of Torts 254, 256-57 (Duncker \& Humblot 2001). In contrast, Epstein argues that the absence of relevant precedents "underscore[s] the uncompromising no-liability rule of the common law." Richard A. Epstein, The Historical Origins and Economic Structure of Workers' Compensation Law, 16 Ga L $\operatorname{Rev} 775,778$ (1982). Karsten similarly views the decision as in accord with prior practice. See Karsten, Heart versus Head at 114-20 (cited in note 3) (noting that precedent and "the taught legal tradition" had more to do with the adoption of the fellow-servant rule rather than "enterprise-minded judges").

57152 Eng Rep 402 (Ex 1842).

58 Id at 405. See also Baker, Introduction to English Legal History at 417 (cited in note 9) ("[A] negligent manufacturer was held to be free from liability except to those who bought directly from him."); Ibbetson, Law of Obligations at 173-74, 295 (cited in note 38) ("The rules of privity enabled [the] claim in contract to be blocked; and his claim in tort foundered."). Ibbetson also notes the "judicial choice" involved in this case. Id at 174 ("[J]udge-made rules, stemming from transparent judicial preferences, meant that negligent manufacturers largely escaped liability for damage caused by their goods."). 
also paid the consideration. ${ }^{59}$ Similarly, the famous case of Hadley $v$ Baxendale ${ }^{\omega 0}$ decided in 1854 , limited contract damages to those that were foreseeable, in spite of conflicting precedents. ${ }^{61}$

The statutory changes in 1799 and 1825 also permit a more quantitative approach to the hypothesis of a pro-plaintiff bias in the common law. If the desire to increase fee income was an important part of judicial motivation to increase caseloads, removal of those incentives should have led to measurable changes in the law. This Part attempts to test that hypothesis in three ways: (1) by comparing all reported cases one year before and one year after the 1799 and 1825 statutes, that is comparing 1798 cases to 1800 cases, and 1824 cases to 1826 cases, (2) by comparing leading cases, as identified by modern historians, in the periods $1600-1798,1800-1824$, and 1826-1872, and (3) by comparing statutes changing the common law in the periods $1600-1798$ and $1800-1872$.

\section{A. Reported Cases: 1798, 1800, 1824, and 1826}

The simplest way to measure the impact, if any, of the 1799 and 1825 statutes taking fees away from the judges, is to compare all reported cases in the year before the statutory change to cases decided the year after. If fees induced the judges to decide cases in a more proplaintiff way, then the removal of fees might be reflected in more prodefendant decisionmaking after the statutes. ${ }^{62}$

On the other hand, if reported cases were a complete or random sample of all litigated cases and if litigants adjusted their settlement behavior to the change in judicial decisionmaking, one might expect that the percentage pro-plaintiff would have been unaffected by the statutes. This, of course, is an application of the famous Priest-Klein selection hypothesis. ${ }^{63}$ Because of the possibility of selection bias, this test of the pro-plaintiff hypothesis is not very strong. Nevertheless, there are three reasons to think an effect might still be detectable. First, Priest and Klein predict no change only in the limit, as prediction errors and thus the amount of litigation go to zero. When there is prediction error and thus litigation, their theory and simulations predict that the percentage pro-plaintiff in litigated cases will vary with

59 See Baker, Introduction to English Legal History at 354-55 (cited in note 9) ("[T]he nineteenth-century King's Bench ... established it as a rigid doctrine that to sue in contract the plaintiff must be privy both to the promise and to the consideration.").

60156 Eng Rep 145 (Ex 1854).

61 See Ibbetson, Law of Obligations at 231 (cited in note 38) (noting the conflicting precedent).

62 See Part III.A.

63 See George L. Priest and Benjamin Klein, The Selection of Disputes for Litigation, $13 \mathrm{~J}$ Legal Stud 1, 2 (1984) (arguing that cases that go to trial are not representative of all disputes). See also Keith N. Hylton, Information, Litigation, and Common Law Evolution, 8 Am L \& Econ $\operatorname{Rev} 33,34$ (2006) (synthesizing research on the selection of disputes since 1984). 
the decision standard, although the change might be too small to detect. $^{6}$ Second, if parties failed to predict the change in judicial decisionmaking caused by the removal of fees, an effect might still appear. Third, since cases that changed the law were more likely to be reported, analyzing all reported cases might indicate the direction in which the law was changing rather than merely the percent proplaintiff in ordinary litigation arising from factual ambiguities.

Table 3 reports the percentage of reported cases that were decided for the plaintiff in the relevant years. Cases are categorized as pro-plaintiff if the plaintiff received all or most of what she had claimed, and pro-defendant if the defendant prevailed. Exchequer was excluded, because only a handful of reports survive for 1798 .

TABLE 3

REPORTED CASES, $1798,1800,1824$, AND $1826^{65}$

\begin{tabular}{lrrrrrr}
\hline & $\begin{array}{c}\text { King's Bench } \\
\% \text { for } \\
\text { plaintiff }\end{array}$ & $\mathrm{N}$ & $\begin{array}{r}\text { Common Pleas } \\
\% \text { for } \\
\text { plaintiff }\end{array}$ & $\mathrm{N}$ & $\begin{array}{r}\text { All } \\
\% \text { for } \\
\text { plaintiff }\end{array}$ & $\mathbf{N}$ \\
\hline 1798 & $56 \%$ & 100 & $54 \%$ & 69 & $55 \%$ & 169 \\
1800 & $40 \%$ & 76 & $60 \%$ & 73 & $50 \%$ & 149 \\
1824 & $43 \%$ & 28 & $53 \%$ & 19 & $47 \%$ & 47 \\
1826 & $35 \%$ & 37 & $67 \%$ & 18 & $45 \%$ & 55 \\
\hline Difference between & & & & & & \\
1798 and 1800 & $-16 \%$ & & $6 \%$ & & $-5 \%$ & \\
Difference between & $-8 \%$ & & $14 \%$ & & $-2 \%$ &
\end{tabular}

Source: The English Reports on CD-ROM (Jutastat, Ltd).

** denotes that the one-tailed $p$-value was less than 0.025 , and thus that the two-tailed $p$-value was less than 0.05 .

The data do not lend themselves to any straightforward analysis. The only statistically significant change (two-tailed $p$-value 0.04 ) is the change in King's Bench from 1798 to 1800 , where there was a 16 per-

64 See Daniel Kessler, Thomas Meites, and Geoffrey Miller, Explaining Deviations from the Fifty-Percent Rule: A Multimodal Approach to the Selection of Cases for Litigation, $25 \mathrm{~J}$ Legal Stud 233, 244-45 (1996) ("[A] change in the decision standard that would decrease the probability of plaintiff victory by $x$ percent, if all disputes were litigated, would decrease the probability of plaintiff victory among actually litigated disputes by less than $x$ percent."); Priest and Klein, The Selection of Disputes for Litigation, $13 \mathrm{~J}$ Legal Stud at 20-23 (cited in note 63).

65 Cases are categorized as "pro-plaintiff" or "pro-defendant" solely based on who won the particular case, not based on a more complex analysis of the case's precedential value. Cases where the plaintiff received some, but not all, of his or her claim, were categorized as 50 percent for the plaintiff. Cases "in error" were excluded, as the incentives for judges in these quasiappellate cases were different. The 1798 and 1800 rows contain all reported cases, while the 1824 and 1826 rows represent the cases from only a single term. 
centage point drop in the percentage of pro-plaintiff decisions. This drop accords with Prediction 1, that removal of fees would reduce the percentage of pro-plaintiff decisions. In contrast, results for the other three changes-King's Bench 1824 to 1826 , Common Pleas 1798 to 1800 , and Common Pleas 1824 to 1826 -are not statistically significant and are of different directions. Pooling King's Bench and Common Pleas cases together yields changes of the predicted sign, although lacking in statistical significance. Most likely, the inconclusive results reflect the selection-bias problem discussed above.

\section{B. Leading Cases Identified by Modern Historians}

Another way of measuring legal change is to look at important cases. The advantage of such cases is that they might avoid the selection bias problem. Important cases are those that decide new and important issues, and thus set influential precedents for the future. Although parties will still settle and litigate such cases strategically, eventually cases posing significant new issues will be litigated. The outcomes of such cases will reveal underlying biases and incentives in judicial decisionmaking, rather than simply strategic selection of cases for settlement or litigation.

Of course, identifying important cases is difficult and potentially subject to bias. In Part IV.B, I use citation in modern legal histories to select cases that, with the benefit of hindsight, have had the greatest impact on the development of the law. As sources for this Part, I used John Baker's Introduction to English Legal History, ${ }^{60}$ David Ibbetson's A Historical Introduction to the Law of Obligations, ${ }^{67}$ and Richard Epstein's Cases and Materials on Torts. ${ }^{68}$ The first two choices need little explanation. John Baker is probably the most distinguished living English legal historian, and his Introduction is a comprehensive and scholarly synthesis. David Ibbetson's book is the most recent history of tort and contract and has been widely acclaimed. Use of Richard Epstein's torts casebook requires a little more justification. Richard Epstein is best known as a modern lawyer and law professor. Nevertheless, he is also an accomplished historian, ${ }^{\infty}$ and his casebook pays close attention to pre-1900 English case law.

The Epstein casebook deals only with tort, and the Ibbetson text covers both tort and contract, as well as related topics such as unjust

\footnotetext{
Baker, Introduction to English Legal History (cited in note 9).

Ibbetson, Law of Obligations (cited in note 38).

Richard A. Epstein, Cases and Materials on Torts (Aspen 8th ed 2004).

69 See generally, for example, Richard A. Epstein, For a Bramwell Revival, 38 Am J Legal Hist 246 (1994) (analyzing the jurisprudence of a nineteenth-century English judge); Epstein, $16 \mathrm{Ga}$ L Rev 775 (cited in note 56) (discussing the historical development of workers' compensation laws).
} 
enrichment. Baker's Introduction to English Legal History covers the entirety of English law, but for this Part, I have examined only the tort and contract chapters. ${ }^{10} I$ chose to focus on tort and contract for two reasons. First, these two subjects composed more than 80 percent of cases brought in the common law courts." Second, the third major common law area, property, presents special problems, because the impact of doctrine on future plaintiffs is especially unclear. For example, it is impossible to say whether the Rule in Shelley's Case ${ }^{2}$ - that a grant to A of a life estate with the remainder in fee simple to A's heirs gives $A$ a fee simple interest - will benefit plaintiffs or defendants. Its primary effect is probably on the drafting of deeds, and only secondarily on who will take possession under the deed and who will challenge it in court. In contrast, in tort cases, the effect of doctrine on plaintiffs and defendants is usually clear. Contract cases present some of the same difficulties as property cases, but it is usually easy to tell which party will benefit from a case-for example, in Slade's Case, ${ }^{73}$ expanding the enforceability of oral contracts will usually benefit plaintiffs, while in Hadley $v$ Baxendale, restricting damages will usually benefit defendants. ${ }^{74}$ Of course, as noted above, "benefit" to plaintiff or defendant, for the purpose of this Article, is measured at the time plaintiff files suit, not ex ante.

The cases analyzed come from the period 1600 to 1872 . The year 1600 was chosen as the starting point because it was clear by that time that the courts had jurisdictions that were almost completely overlapping, and thus the hypothesis of competition is most plausible from this point onward. The year 1872 is a logical end point, because the 1873 and 1875 Judicature Acts consolidated the courts and thus eliminated any possibility of competition between them.

70 See Baker, Introduction to English Legal History at 317-465 (cited in note 9). Like Ibbetson's book, these chapters also include quasi-contract and unjust enrichment, which are therefore included in the statistics.

71 Christopher W. Brooks, Lawyers, Litigation and English Society Since 1450 52-53 (Hambledon 1998) (charting percentages of the types of cases heard by King's Bench and Common Pleas in 1640 and 1750).

72 Wolfe $v$ Shelley, 76 Eng Rep 206 (KB 1581).

73 Slade v Morely, 76 Eng Rep 1072 (KB 1602).

74 Ex ante, it is not clear that one side will benefit, as prices and other terms may adjust to reflect anticipated litigation outcomes. Nevertheless, when judged at the time litigation is initiated, it is clear which side benefits. For the purposes of this article, the time of suit is the relevant time frame. Benefit is measured in comparison to the previous state of the law (for example, limited enforcement of oral contracts before Slade's Case) or the alternative rule argued to the court (for example, full damages in Hadley).

75 See Part III.A.1.

76 Statute of 38 \& 39 Vict ch 77 (1875); Statute of 36 \& 37 Vict ch 66 (1873). See also Baker, Introduction to English Legal History at 50-51 (cited in note 9) (noting that the Judicature Act of 1873 abolished the three common law courts and combined them into one High Court). 
TABLE 4

LEADING CASES IDENTIFIED BY MODERN HiSTORIANS, 1600-1872

\begin{tabular}{|c|c|c|c|c|c|}
\hline & $\begin{array}{c}\text { Baker } \\
\% \text { for } \\
\text { plaintiff } \quad N\end{array}$ & $\begin{array}{l}\text { Ibbetson } \\
\% \text { for } \\
\text { plaintiff } \quad N\end{array}$ & $\begin{array}{r}\text { Epst } \\
\% \text { for } \\
\text { plaintiff }\end{array}$ & $\mathbf{N}$ & $\begin{array}{c}\text { All } \\
\% \text { for } \\
\text { plaintiff } \quad \mathrm{N}\end{array}$ \\
\hline $1600-1798$ & $76 \% 192$ & $64 \% 138$ & $58 \%$ & 19 & $69 \% 302$ \\
\hline $1800-1824$ & $70 \% \quad 20$ & $50 \% \quad 35$ & $33 \%$ & 6 & $56 \% \quad 57$ \\
\hline$\underline{1826-1872}$ & $56 \% \quad 36$ & $62 \% \quad 103$ & $38 \%$ & 28 & $57 \% \quad 143$ \\
\hline $1800-1872$ & $61 \% \quad 58$ & $60 \% \quad 140$ & $39 \%$ & 35 & $57 \% \quad 203$ \\
\hline $\begin{array}{l}\text { Difference between } 1600-1798 \\
\text { and } 1800-1824\end{array}$ & $-6 \%$ & $-14 \%$ & $-25 \%$ & & $-13 \% *$ \\
\hline $\begin{array}{l}\text { Difference between 1800-1824 } \\
\text { and } 1826-1872\end{array}$ & $-14 \%$ & $-12 \%$ & $5 \%$ & & $1 \%$ \\
\hline $\begin{array}{l}\text { Difference between 1600-1798 } \\
\text { and } 1800-1872\end{array}$ & $-15 \% * *$ & $-4 \%$ & $-19 \%$ & & $-12 \% * *$ \\
\hline
\end{tabular}

In all three texts, there was a drop in the percentage of cases that were pro-plaintiff after 1799. In Baker's Introduction to English Legal History, the drop between 1600-1798 and 1800-1824 was 6 percentage points; in Ibbetson, the drop was 14 percentage points, and in Epstein the drop was 25 percentage points. Although, taken alone, none of these changes is statistically significant, if one pools the cases from all three sources, the drop is 13 percentage points and is statistically significant, albeit only marginally. ${ }^{78}$ Comparing the period $1600-1798$ to the longer period, 1800-1872, confirms the idea that the drop seen

77 . Cases cited by Baker and Epstein were coded primarily based on Baker's and Epstein's descriptions of their holdings. Where these descriptions were ambiguous, I read the cases themselves and coded them in accordance with their outcomes. The pro-plaintiff or pro-defendant character of a case in Ibbetson's descriptions was so frequently ambiguous that I always coded cases by reading them and coding their outcomes. Cases decided by courts "in error" or by the House of Lords were excluded, as the incentives of appellate (or quasi-appellate) courts were different. The row labeled "1800-1872" includes cases from 1825, which are not included elsewhere in the table. As a result, this row does not merely combine information in the prior two rows. Where two sources (for example, Baker and Ibbetson) both identified the same case, it was counted only once in the "All" column.

78 Statistical significance was evaluated conservatively, using a 2-sided test and classifying $p \leq 0.05$ as statistically significant and $0.05<p \leq 0.10$ as marginally statistically significant. On the other hand, because Prediction 1 is that the percentage pro-plaintiff would decline after 1799, the null hypothesis is that the percentage pro-plaintiff stayed the same or increased. Therefore it would be appropriate to use the 1-sided test, under which the difference between 1600-1798 and $1800-1824$ is statistically significant $(p=0.3)$ for all sources combined and marginally statistically significant for Ibbetson $(p=0.6)$. 
immediately after 1799 was durable. In all three sources, the percentage of pro-plaintiff decisions fell, and the drops are statistically significant for Baker and the three sources combined, although not for Epstein and Ibbetson alone.

On the other hand, there is no evidence that the 1825 statute that took fees away from the Chief Judges of King's Bench and Common Pleas had any effect. The cases in Baker show a large, 12 percentage point drop in the percent pro-plaintiff, but Ibbetson and Epstein show small increases. Overall, there is a slight ( 3 percentage points) increase in the percent pro-plaintiff. None of these changes is statistically significant. Most probably, the 1825 statute had little impact because all cases in the examined reports were decided en banc by all four judges in the court. Since the chief was only one of the four, the change in his incentives had little effect. In addition, the 1825 statute had no effect on the Court of Exchequer because fees from all its judges were taken away in 1799 .

Taken together, the analysis of important cases as identified by modern historians is consistent with Prediction 1 . When fees were taken away from most judges, the proportion of doctrinally important cases in which the court ruled for the plaintiff fell 16 percent, from 69 percent to 57 percent. $^{79}$

79 Analysis by subperiods largely confirms this conclusion. The table below shows the percentage pro-plaintiff by twenty-five year groupings:

\begin{tabular}{lrc} 
& \% for plaintiff & $\mathbf{N}$ \\
\hline $1600-1624$ & $73 \%$ & 68 \\
$1625-1649$ & $78 \%$ & 27 \\
$1650-1674$ & $64 \%$ & 50 \\
$1675-1699$ & $64 \%$ & 39 \\
$1700-1724$ & $79 \%$ & 28 \\
$1725-1749$ & $77 \%$ & 13 \\
$1750-1774$ & $78 \%$ & 27 \\
$1775-1798$ & $54 \%$ & 50 \\
$1800-1824$ & $56 \%$ & 57 \\
$1826-1849$ & $61 \%$ & 80 \\
$1850-1872$ & $52 \%$ & 63
\end{tabular}

Notes: As in Table 4, 1799 and 1825 were excluded because they were the years of the statutory change, and 1873 and 1874 were excluded because the courts were consolidated in 1873 .

There is no consistent trend in the data, neither before 1799 nor after 1799 . In addition, with one exception, the percentage pro-plaintiff in every period after 1799 is lower than in every period before 1799 . The one exception is $1775-1798$, which has a low percentage pro-plaintiff. The low percentage in the period $1775-1798$ is potentially troubling, as it might suggest that some cause other than the 1799 fee statute might explain the lower percentage pro-plaintiff in the period 1800-1872. Closer examination of the period 1775-1798 reveals that this is implausible. The low percentage in this period is driven largely by nine pro-defendant cases from single sixyear period (1790-1795), all from a single court (King's Bench) and all cited by a single source 
C. Statutes, 1600-1872

As discussed above, Prediction 2 suggests that pre-1799 statutes should tend to change the law in pro-defendant ways, because the courts were biased in favor of the plaintiff. After 1799, Prediction 3 suggests that statutes should be less pro-defendant, and perhaps even pro-plaintiff. One problem is identifying the relevant universe of statutes. Most statutes deal with revenue or military concerns, and have no effect on the volume of litigation or judicial fees. One promising way of identifying the relevant statutes is to see which statutes are cited in modern works of English legal history. I have done this for three sources - tort and contract statutes cited in Baker's Introduction to English Legal History, statutes cited in Ibbetson's Historical Introduction to the Law of Obligations, and statutes cited in A.W.B. Simpson's $A$ History of the Common Law of Contract. ${ }^{80}$ The first two sources were discussed above and need no further explanation. Epstein's casebook cites relatively few English statutes and thus could not be used again. Simpson is a leading legal historian and his history of contract law is widely cited, so analysis of statutes discussed in his book is illuminating.

As before, the period 1600-1872 was chosen for analysis. Unfortunately, the sources analyzed here cite only two statutes from the period $1800-1824$, so that subperiod cannot be analyzed separately. Table 5 below presents the results.

(Ibbetson). This suggests that the drop in the period 1775-1798 did not reflect a general cause which might have persisted into the nineteenth century, but rather a peculiarity of 1790-1795, King's Bench, and/or Ibbetson's selection of cases.

80 Simpson, A History of the Common Law of Contract (cited in note 22). 
TABLE 5

STATUTES AFFECTING TORT AND CONTRACT, 1600-1872

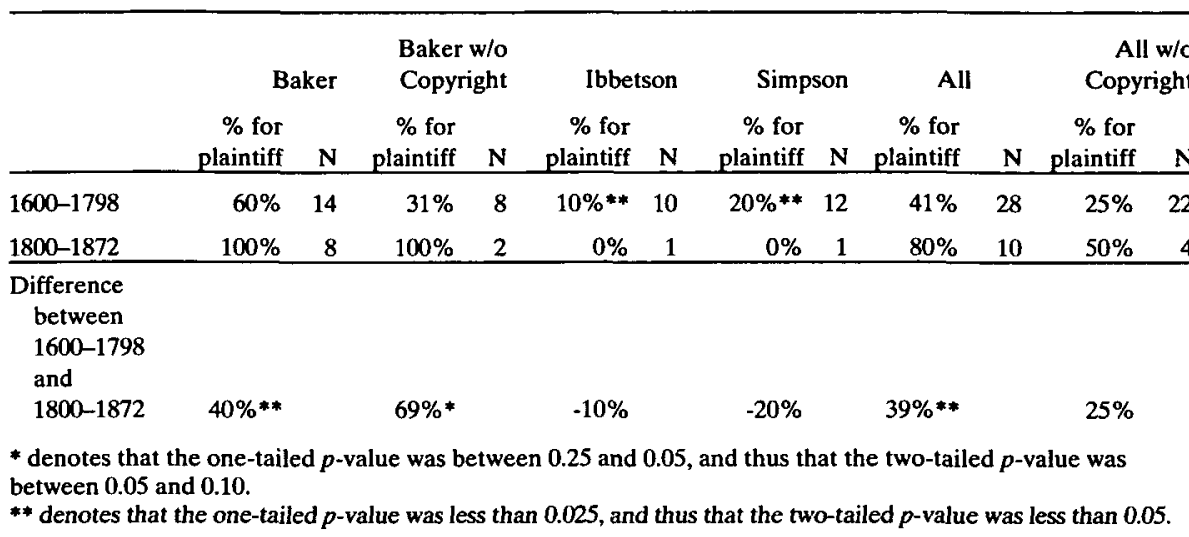

The results in the table are broadly consistent with the predictions. Look first at the statutes in the Ibbetson and Simpson treatises. The pro-defendant character of legislation before 1799 is manifest. Only 10 or 20 percent of statutes were pro-plaintiff. For both, the percentage pro-plaintiff is significantly different from 50 percent, with $p$ values less than 0.05 . The statutes cited in Baker's text are more ambiguous. If one looks at all the 1600-1798 statutes, a majority (60 percent) were pro-plaintiff, which is inconsistent with Prediction 1. When one looks more deeply, one notices that more than two-thirds of the pro-plaintiff statutes deal with copyright and are the legislative reaction to a single decision, Donaldson $v$ Beckett, ${ }^{82}$ which held that there was no common law copyright. ${ }^{83}$ If copyright statutes are excluded, the percentage pro-plaintiff drops to 31 percent, which is consistent with the prediction of pro-defendant legislation before 1799, although 31 percent is not statistically different from 50 percent.

81 For the first row, the null hypothesis was that the proportion was equal to 50 percent (a two-tailed test) or greater than 50 percent (a one-tailed test). For the last row, the null hypothesis was that there was no difference between $1600-1798$ and $1800-1872$ (two-tailed) or that the proportion pro-plaintiff was lower in 1800-1872 than in 1600-1798 (one-tailed). Statutory citations were identified using the Table of Statutes at the beginning of each book. Ibbetson's book does not a have Table of Statutes, so statutes were located by skimming the footnotes and by GooglePrint searches. The pro-plaintiff or pro-defendant character of the statute was identified using Baker, Ibbetson, or Simpson's description of the statute. Statutes that did not relate to contracts or torts or that had no clear pro-plaintiff or pro-defendant bias were excluded. Where two sources (for example, Baker and Ibbetson) both identified the same statute, it was counted only once in the "All" and "All w/o Copyright" columns.

821 Eng Rep 837 (HL 1774).

83 Id at 847,849 . 
While the exclusion of copyright statutes may seem ad hoc, it actually provides further support for the hypothesis that common law decisions were ordinarily pro-plaintiff. The decision holding that there was no common law copyright was not made by one of the regular common law courts. In fact, King's Bench had held that there was common law copyright in 1769 . $^{\text {s }}$ The issue came before Parliament only because the House of Lords held to the contrary in $1774 .{ }^{85}$ While proceedings before the House of Lords were a part of the common law process, they were rare and were not subject to the same proplaintiff pressures as cases in King's Bench, Common Pleas, and Exchequer. Unlike the ordinary courts, where the plaintiff chose the forum, the House of Lords heard cases primarily pursuant to writs of error. Such cases were like appeals in that the party which lost below initiated the proceedings. Since the party who lost below might be the defendant, even if the House of Lords wanted to increase its caseload (which is unlikely ${ }^{86}$ ), there is no reason to think it would do so by systematically favoring the plaintiff.

The figures for statutes since 1800 are also largely consistent with the prediction that when fees were taken away, courts shifted towards defendants so statutes would become more pro-plaintiff. The statutes cited by Baker are exclusively pro-plaintiff, and the difference between the pre-1799 and post-1799 statutes is statistically significant, whether copyright statutes are excluded or not. Nevertheless, the number of post-1799 statutes cited by Baker is small, so the results should be interpreted with caution. Nineteenth century statutes cited by Ibbetson and Simpson were pro-defendant, which is inconsistent with the prediction. Nevertheless, they each cite only a single statute. Pooling the statutes cited by Baker, Ibbetson, and Simpson and excluding duplicate citations, there are sizable shifts in the prodefendant direction ( 25 or 39 percentage points), although, because of the small numbers, only the shift that includes the copyright statutes is statistically significant.

Taken together, the statutory analysis is largely consistent with Predictions 2 and 3 . Statutes were overwhelmingly pro-defendant before 1799, and the proportion pro-plaintiff doubled after 1799.

84 See Millar v Taylor, 98 Eng Rep 201, 229 (KB 1769).

85 See Donaldson, 1 Eng Rep at 847.

86 Whether the members of the House of Lords received fee income from cases is unclear, but even if they did, the fees would presumably be split among the many members of the body, most of whom were phenomenally wealthy and thus unlikely to be influenced by prospective fee income. 


\section{ADDITIONAL ISSUES}

This Part discusses a number of additional issues, some of which are topics for future research.

\section{A. Arbitration and Choice-of-Forum Clauses}

Many of the examples in this Article come from contract law. If there really was an inefficient pro-plaintiff bias, however, one might have expected parties to have contracted around it. There are two ways they might have done so: arbitration and choice-of-forum clauses.

Choice-of-forum clauses, if widely used, would have encouraged the courts to develop efficient contract law, rather than pro-plaintiff doctrine, because rational parties would choose the court that had developed rules that maximized their joint surplus. I am unaware of any use of such clauses, or any litigation about them.

One reason such clauses might not have been used is that there was seldom any real disagreement between the courts. This is the prediction of the game theoretic analysis in Part III and the Appendix. In equilibrium, the courts almost always choose the same decision standard. The absence of disagreement between the courts also accords with the historical record, where each court usually adopted the innovations of the other. As a result, it would not usually have been worthwhile for contracting parties to include such clauses. Since they were used infrequently, if at all, courts had no incentive to develop efficient law. Of course, a court might have thought it could develop a competitive advantage by creating efficient law and then hoping parties would use forum selection clauses to increase the caseload of that court. Even if a court could really have counted on widespread use of forum selection clauses, this strategy might not have been beneficial if, as is likely, efficient rules would have generated less litigation.

Enforcement of forum selection clauses might have been another potential problem, although probably not a fatal one. If the contract specified the Court of Common Pleas, but the plaintiff chose King's Bench, King's Bench would obviously have an incentive not to enforce the choice-of-forum clause. On the other hand, at least before 1697 , contracting parties could have backed up their choice-of-forum clauses with a penalty bond stipulating large penalties for violation of the choice-of-forum clause. In that situation, if the plaintiff violated the choice-of-forum clause and brought the case in King's Bench, the defendant could sue on the penalty bond in Common Pleas. In that situation, Common Pleas would obviously have an incentive to enforce the penalty bond. If the amount of the penalty bond were sufficiently high (that is, greater than the difference between expected damages in King's Bench and Common Pleas), the threat of penalty 
bond enforcement would give the plaintiff an incentive to obey the choice-of-forum clause and sue in Common Pleas in the first place.

The existence of arbitration, like the possibility of statutory override, could have constrained the pro-plaintiff bias. On the other hand, because of the transactions costs of drafting arbitration clauses and the costs of arbitration itself, there might have been a wide range of pro-plaintiff decisions that would not have provoked parties to resort to arbitration.

It is often said that the common law was hostile to arbitration, and this attitude is sometimes attributed to the judges' pecuniary interests. Some have argued that judges made arbitration agreements unenforceable because arbitration would have reduced their incomes by diverting cases from the courts. ${ }^{87}$ This analysis is too simplistic. It overlooks competition between the courts. While the judges collectively would have had an interest in discouraging arbitration, each court might have seen it as in its own interest to enforce arbitration agreements. By enforcing arbitration agreements, such a court might reduce its own docket of cases on the merits, but it would gain arbitration enforcement cases that might otherwise have gone to one of the other courts. Courts thus may have faced a collective action problem. It might have been in their collective interest to void arbitration agreements, but in their individual interests to enforce them. Decisions on arbitration thus provide an interesting window into the extent to which courts acted individually (for example, competitively) or collectively (for example, collusively or cooperatively).

In the medieval and early modern periods, arbitration agreements were usually enforced by penal bonds. That is, the parties entered into an agreement in which they agreed to arbitrate, each promising to pay some large sum as a penalty if it did not arbitrate or abide by an arbitration award. Such bonds, like most penal bonds, were enforceable. Even Vynior's Case, ${ }^{88}$ which is often cited as evidence of common law hostility to arbitration because it held that either party could revoke the arbitrator's authority, held that the party that revoked the arbitrator's authority forfeited the bond amount. ${ }^{89}$ Thus, as long as the parties stipulated a large enough penalty, arbitration agreements would be effective.

Unfortunately, the power of penal bonds to back up arbitration agreements was eviscerated by the 1697 and 1705 statutes mentioned

87 See Bruce L. Benson, An Exploration of the Impact of Modern Arbitration Statutes on the Development of Arbitration in the United States, 11 J L Econ \& Org 479, 483 (1995) (observing that judges' incentives "were to eliminate competition and absorb all dispute resolution").

8877 Eng Rep 597 (KB 1607).

89 Id at 601 . 
above, which made penalty clauses unenforceable. ${ }^{0}$ Nevertheless, as Henry Horwitz and James Oldham have shown, even after these statutes, courts continued to enforce arbitration agreements using their contempt power. ${ }^{91}$ Their ability to do so was bolstered by a 1698 statute, ${ }^{2}$ but judges were already using rules of court to enforce arbitration agreements even before these statutes were passed. Although eighteenth- and nineteenth-century decisions such as Kill v Hollister are often cited as evincing hostility to arbitration, Horwitz and Oldham have shown that the printed versions of these cases are inaccurate and that the actual decisions supported arbitration. ${ }^{94}$

\section{B. Collective Action Problems within Courts}

This Article has so far assumed that each court acted as a single unit, rationally maximizing its income. This is a grave simplification, as the courts were composed of numerous individuals whose interests might conflict. Depending on the ability of certain actors to veto changes, reforms which might benefit the court as a whole might be blocked by those whose incomes would be adversely affected.

Blatcher presents a tantalizing hint of the possible importance of the internal structure of courts. Why was the Bill of Middlesex (a procedural fiction that increased jurisdiction and reduced cost) developed in King's Bench rather than Common Pleas? Blatcher suggests part of the answer lies in the allocation of responsibility among court staff. In King's Bench, a single prothonotary (chief clerk) had the power and financial incentive to innovate. In Common Pleas, the prothonotary's responsibilities were split among three men, and change would also have required the assent of an independent keeper of the seal. ${ }^{95}$ Thus, collective action problems may have impeded innovation in Common Pleas.

Similarly, practice in Common Pleas was restricted to serjeants, an elite subset of the bar. While this monopoly enriched the serjeants, it raised costs and thus gave King's Bench an advantage. In parallel

90 See note 45 and accompanying text.

91 Henry Horwitz and James Oldham, John Locke, Lord Mansfield, and Arbitration during the Eighteenth Century, 36 Hist J 137, 156 (1993) (noting that a party to an arbitration agreement could have the agreement entered as a rule of court, which was then enforceable by the court's contempt power).

92 Statute of 9 Will III ch 15 (1698) (providing procedure for better enforcement of arbitration agreements).

9395 Eng Rep 532 (KB 1746).

94 See Henry Horwitz and James Oldham, Arbitration and Royal Courts in the 18th Century 39-45 (unpublished manuscript, 1989) (noting that manuscript reports of Kill $v$ Hollister show that the main issue in the case was contractual interpretation, and that hostility to arbitration was expressed only in dicta and by only a few judges).

95 Blatcher, The Court of King's Bench at 109-10 (cited in note 31). 
fashion, the four sworn attorneys and sixteen side clerks had a monopoly of the common law business in Exchequer. ${ }^{\text {* }}$ Although these practice restrictions impeded their courts' ability to compete, those who benefited fought to retain them.

\section{How Did the Fee System Work?}

While it is relatively clear that judges received fees, the details of the system are uncharted. How were fees distributed between chief and puisne (nonchief) judges? Between judges and staff? Between staff members? When did the fee system begin and how did it evolve? Did changes in the fee system affect legal evolution? Did competition produce pressure to lower fees?

\section{Procedure}

This Article has focused on legal doctrine. Competition could also affect procedure. Does the evolution of common law procedure accord with the hypothesis of a pro-plaintiff bias?

\section{E. Quasi-Appellate Cases}

Although there was no true system of appeals before the midnineteenth century, proceedings "in error" provided a limited form of appellate review. By this method, King's Bench had the power to review cases from Common Pleas. Cases from King's Bench and Exchequer were reviewed by ad hoc courts composed mostly of judges from other courts and ultimately by the House of Lords. Proceedings in error, however, were very circumscribed because the reviewing court could examine only the official legal record. Since the legal record did not include evidence presented at trial and was often obscured by unreviewable legal fictions," proceedings in error did not provide an effective constraint on the separate development of law and procedure in each court. Nevertheless, they probably did encourage one of the distinctive features of English law - the proliferation of legal fictions-because fictions enabled courts to expand their jurisdictions without correction by proceedings in error. ${ }^{98}$

96 First Report Made to His Majesty by the Commissioners Appointed to Inquire into the Practice and Proceedings of the Superior Courts of Common Law 211 (1829), in Great Britain. House of Commons. Parliamentary Papers (1801-1900) (Chadwyck-Healey Microform 1980-82).

97 For a brief discussion of legal fictions, see Baker, Introduction to English Legal History at 201 (cited in note 9) ("[Sir Henry] Maine used the term Legal Fiction in its widest sense, to signify any assumption which conceals, or affects to conceal, the fact that a rule of law has undergone alteration, its letter remaining unchanged, its operation being modified.").

98 See note 30 and accompanying text. 
Courts in error had different incentives from King's Bench and the other ordinary common law courts. If they collected fees, which I suspect they did, they would have an incentive to favor appellants, who were the ones who chose whether to appeal. Nevertheless, it would have been difficult to systematically favor appellants through doctrinal choice, because any doctrine would just change the nature of future appellate cases. Courts of error might favor uncertain rules, as they might provoke more litigation and more appeals. In addition, since these quasi-appellate courts were often composed of judges from competing courts, appellate courts could facilitate collusion or allow one court to undercut the competitive position of a rival. In any case, there is little reason to predict a pro-plaintiff bias in proceedings in error. The decisions of such courts could thus provide a useful control for the trial courts analyzed in the bulk of this Article.

\section{F. Alternative Explanations}

While this Article argues for the importance of fees and competition, there are other potential explanations for some of the patterns discussed here. Perhaps class or ideological biases can explain the results. Perhaps judges were pro-plaintiff in contract cases, because of a class bias in favor of creditors. Perhaps they were pro-defendant in Priestly and Winterbottom, because of class bias against employees and consumers. Alternatively, it is possible that the common law rigidly enforced contracts while Chancery developed defenses, because of differences in institutional competence. Perhaps defenses were too complex for the common law courts, which relied on lay juries, and required the sort of nuanced factfinding that only Chancery's professional judging could provide. While these explanations have some plausibility, they cannot explain the broad shifts in judicial decisionmaking around 1799.

One alternative explanation that can be rejected is that judges became more pro-defendant after 1799 because they generally favored business. Although such a hypothesis might be plausible in America, ${ }^{99}$ early nineteenth century English judges were drawn primarily from the gentry and had little sympathy with business. In fact, as Ron Harris has documented, some early nineteenth century deci-

99 Horwitz, Transformation of American Law, 1780-1860 at 140 (cited in note 4) ("In the period between 1790 and 1820 we see the development of an important new set of relationship...the forging of an alliance between legal and commercial interests."). But see generally Robert W. Gordon, Morton Horwitz and his Critics: $A$ Conflict of Narratives, 37 Tulsa L Rev 915 (2002); Karsten, Heart versus Head (cited in note 3); A.W.B. Simpson, The Horwitz Thesis and the History of Contracts, 46 U Chi L Rev 533 (1979); Stephen Williams, Transforming American Law: Doubtful Economics Makes Doubtful History, 25 UCLA L Rev 1187 (1978). 
sions called into question the legality of a common form of business organization (the unincorporated company), thus potentially destroying millions of pounds (billions of dollars) of investment. ${ }^{100}$

\section{CONCLUSION}

In modern times, judges are largely insulated from monetary incentives, so it is unsurprising that historians of nineteenth- and twentieth-century law look to factors like precedent, ideology, class background, and social change to understand legal evolution. In earlier times, the institutional setting of the judiciary may have provided financial incentives which directly affected decisionmaking. Since much of current law was shaped in pre-modern times, a full understanding of legal history requires attention to the ways in which incentives and other aspects of institutional structure affected judicial decisionmaking.

This Article draws attention to two structural features of the English legal system before 1800: judicial fee income and courts with overlapping jurisdiction. These two structures suggest a relatively simple hypothesis: that competition among courts led to a pro-plaintiff bias in the common law. This idea is supported by quantitative analysis of decisionmaking before and after passage of the 1799 statute that dampened competition by taking fees away from the judges. Jurisdictional competition and its statutory abolition also help explain some important cases and historical patterns, including the remarkable underdevelopment of contract defenses at common law and the prodefendant character of nineteenth century tort doctrine. 


\section{APPENDIX \\ A FORMAL MODEL OF JURISDICTIONAL COMPETITION}

Of course, the examples in Part III.A do not prove the proplaintiff bias. In particular, the argument in Figure 4 works only if the intermediate standard reduces litigation by less than 50 percent compared with the pro-defendant standard, and the pro-plaintiff rule reduces litigation by less than 50 percent compared with the intermediate standard. This appendix introduces a formal model that proves the pro-plaintiff bias more generally and makes explicit the conditions under which the bias occurs.

\section{A. The Basic Model}

Let $d_{i}$ be a possible decision standard for a given set of cases, where $i$ is a positive integer, $1 \leq i \leq N$, and $N$ is a positive integer and $N \geq 2$. Let $d_{1}$ represent the most pro-defendant rule (for example, no liability), $d_{N}$ represents the most pro-plaintiff rule (for example, strict liability), and intermediate values represent possible standards (gross negligence, ordinary negligence, strict liability etc.), with $d_{i+1}$ representing a more pro-plaintiff decision standard than $d_{i}$. To simplify the notation, let $d_{i}<d_{j}$ mean $i<j, d_{i}>d_{j}$ mean $i>j$, and $d_{i}=d_{j}$ mean $i=j$. That is, more pro-plaintiff decision standards are "greater than" prodefendant decision standards. Let $d_{\mathrm{KB}}$ represent the decision standard chosen by King's Bench, which, for convenience, I will assume chooses the rule first, and let $d_{\mathrm{CP}}$ represent the decision standard chosen by Common Pleas.

Let $q$ denote the number of cases, where $q$ is a nonnegative integer. Because parties rationally anticipate that the plaintiff will choose the court which has chosen the more pro-plaintiff rule, $q=q\left(\max \left(d_{\mathrm{KB}}, d_{\mathrm{CP}}\right)\right)$. Assume only that $q\left(d_{1}\right)=0$ and $q\left(d_{i+1}\right)>1 / 2 q\left(d_{i}\right)$ for all $i<\mathrm{N}$. The first assumption about $q$, that there is no litigation under the most prodefendant rule (no liability) makes sense because if the rule is no liability, there is no reason for there to be any litigation at all. The second assumption about $q$ means that an incremental change in the decision standard never reduces the quantity of litigation by more than 50 percent. This assumption makes sense, because there are a very wide range of possible decision standards, so for any decision standard, there will always exist a decision standard that is only slightly different and slightly more pro-plaintiff, and thus should not produce a drastic change in the amount of litigation. This would be similar to an assumption of continuity, if one were to assume that decision standards formed a continuum rather than being discrete. Of course, the second assumption does not exclude the possibility that a shift in the pro-plaintiff direction 
might increase the amount of litigation. Note also that the assumption that $q\left(d_{i+1}\right)>1 / 2 q\left(d_{i}\right)$ implies that $q\left(d_{i}\right)>0$ for all $i>1$.

Let $q_{\mathrm{KB}}$ and $q_{\mathrm{CP}}$ denote the number of cases received by each court, with the following properties:

$$
\begin{aligned}
q_{\mathrm{KB}} & =q-q_{\mathrm{CP}} \\
& =0, \text { if } d_{\mathrm{KB}}<d_{\mathrm{CP}} \\
& =1 / 2 q, \text { if } d_{\mathrm{KB}}=d_{\mathrm{CP}} \\
& =q, \text { if } d_{\mathrm{KB}}>d_{\mathrm{CP}}
\end{aligned}
$$

These properties formalize the idea, discussed above, that plaintiffs choose the court that has chosen the more pro-plaintiff rule and randomize if both courts have chosen the same rule.

For simplicity, assume that there is only one judge on each court, with each judge denoted by his court, $\mathrm{KB}$ or $\mathrm{CP}$. Let $\lambda$ denote the utility a judge receives from hearing a single case, where $\lambda$ is any real number. Positive $\lambda$ indicates that judges prefer a higher caseload, perhaps because they receive fee income or get prestige from deciding cases. Negative $\lambda$ indicates they prefer a lower caseload, perhaps because they value leisure more than fee income or prestige, or because they receive no fee income at all. For simplicity, judges are assumed to be homogeneous, and their utility functions are $U_{\mathrm{KB}}=\lambda q_{\mathrm{KB}}$ and $U_{\mathrm{CP}}=\lambda q_{\mathrm{CP}}$. Since it is assumed that there is only one judge per court, I will refer to judges and their courts interchangeably.

Proposition 1. If judges choose only strategies which are subgame perfect Nash equilibria:

(a) if $\lambda>0$, then both courts choose the pro-plaintiff rule, that is, $d_{\mathrm{KB}}=d_{\mathrm{CP}}=d_{N}$.

(b) if $\lambda<0$, then both courts choose the pro-defendant rule, that is, $d_{\mathrm{KB}}=d_{\mathrm{CP}}=d_{1}$.

(c) if $\lambda=0$, then any combination of decision standards is possible.

Proof.

(a) To fully understand why $d_{\mathrm{KB}}=d_{\mathrm{CP}}=d_{N}$, if $\lambda>0$, one must specify the underlying equilibrium strategies, including those off the equilibrium path. KB's strategy is to choose $d_{N}$, and CP's strategy is to choose $d_{N}$ if $\mathrm{KB}$ has chosen $d_{N}$, and to choose $d_{j}$ such that $j>i$ and $q\left(d_{j}\right)$ is as large as possible if KB has chosen $d_{i}$ where $i<\mathrm{N}$. This pair of strategies is a Nash equilibrium, because if $\mathrm{KB}$ and $\mathrm{CP}$ both choose $d_{N}$, then each judge receives utility $1 / 2 \lambda q$. This utility is greater than zero, because $\lambda$ and $q$ are greater than zero. $q$ is greater than zero, because $N>1$. If $\mathrm{KB}$ has chosen $d_{N}, \mathrm{CP}$ could not do better by chang- 
ing the decision rule of his court, because any change would be in a pro-defendant direction (because $1 \leq i \leq N$ ), which would induce all plaintiffs to litigate in $\mathrm{KB}$, thus reducing CP's caseload, and thus his utility, to zero. KB could not do better by changing the decision rule of his court to $d_{i}, i<N$, because CP's strategy would then be to choose a more proplaintiff rule, in which case CP would get all the cases, and KB's caseload and thus utility would be zero. This pair of strategies is subgame perfect, because if $\mathrm{KB}$ has chosen $d_{i}$ where $i<N$, then CP's best strategy is to choose $d_{\text {s such that }}$ $j>i$ and $q\left(d_{j}\right)$ is as large as possible. Since $q\left(d_{j}\right) \geq q\left(d_{i+1}\right)$ $>1 / 2 q\left(d_{i}\right)$ for all $i<N$, its caseload is sure to rise.

There are no subgame perfect Nash equilibrium strategies which do not lead both courts to choose $d_{\mathrm{KB}}=d_{\mathrm{CP}}=d_{N}$. This conclusion flows from the analysis above. There is no Nash equilibrium in which $d_{\mathrm{KB}}=d_{N}$ and $d_{\mathrm{CP}} \neq d_{N}$, because CP could always increase its caseload by choosing $d_{\mathrm{N}}$. Similarly, there is no Nash equilibrium in which $d_{\mathrm{KB}} \neq d_{N}$, because CP's best response to such a strategy is always to choose a more proplaintiff rule, in which case $\mathrm{KB}$ will receive no cases, which is worse than its payoff if it chooses $d_{N}$.

(b) To fully understand why $d_{\mathrm{KB}}=d_{\mathrm{CP}}=d_{1}$, if $\lambda<0$, one must again specify the underlying equilibrium strategies, including those off the equilibrium path. KB's strategy is to choose $d_{1}$, and CP's strategy is to choose $d_{1}$ if $\mathrm{KB}$ has chosen $d_{1}$ and to choose any $d_{k}$, where $k<i$, if $\mathrm{KB}$ has chosen $d_{i}$ where $i>1$. This pair of strategies is a Nash equilibrium, because if KB has chosen $d_{1}, \mathrm{CP}$ cannot do any better by choosing some other (more pro-plaintiff) decision standard, because if it were to do so it would get all of the cases, and the total caseload would be higher, because $q_{1}<q_{i}$ for all $i>1$. Since $U=\lambda q$ and $\lambda<0$, a higher caseload is less preferable. Similarly, KB could not do better by choosing $d_{i}$ where $i>1$, because CP would choose a more pro-defendant rule, leaving $\mathrm{KB}$ with all the cases, which is certainly worse than $1 / 2 q\left(d_{1}\right)$. This pair of strategies is subgame perfect, because if if $\mathrm{KB}$ has chosen $d_{i}$ where $i>1$, CP's best response is to choose a more pro-defendant decision standard, which will shift the entire caseload to KB, which, given $\lambda<0$, is preferable.

(c) If $\lambda=0$, judicial utility is always zero, because $U=\lambda \mathrm{q}$. The choice of decision standard is irrelevant, so any pair of strategies is a subgame perfect equilibrium. 
B. A Model with Judicial Preferences about the Content of the Law

The analysis so far, both in illustrations and in the formal model, has assumed that judges cared only about their caseloads. This Section introduces a further consideration: judges also care about the content of legal rules. Perhaps they care about fairness, social welfare, economic growth, adherence to precedent, predictability, ideology, the welfare of particular classes of people, the congruence of law with religious teaching, or other factors. Such preferences will be referred to as "intrinsic preferences," as distinct from preferences relating to caseload $(\lambda)$, which will be referred to as "caseload preferences." In particular classes of cases, intrinsic preferences may lead judges, setting aside caseload considerations, to favor a particular decision standard, perhaps a pro-defendant or pro-plaintiff rule or perhaps some particular standard. This Section explores the implications of such preferences for judicial decisionmaking.

Let $v\left(d_{i}\right)$ be a judge's intrinsic preference function. Assume only (i) that $v\left(d_{i}\right)$ is single-peaked, and (ii) that if $v\left(d_{i}\right)+\lambda>0$ and $v\left(d_{i+1}\right)+$ $\lambda>0$, then $\left(v\left(d_{i+1}\right)+\lambda\right) q\left(d_{i+1}\right)>1 / 2\left(v\left(d_{i}\right)+\lambda\right) q\left(d_{i}\right)$. By single peaked, $\mathbf{I}$ mean that (a) there is a decision standard, $d_{i^{*}}$ such that $v\left(d_{i^{*}}\right)$ is larger than $v\left(d_{i}\right)$ for all other $i$; (b) for all $d_{i}, i<i^{*}$, if there are any, $v(d)$ is increasing; and (c) for all $d_{i}, i>i^{*}$, if there are any, $v(d)$ is decreasing. The second assumption, as will be clearer after the judicial utility function is defined below, merely states that incremental changes in the decision standard do not drastically change judicial utility. This would be similar to an assumption of continuity, if one were to assume that decision standards formed a continuum rather than being discrete.

Now modify the judicial utility function to include intrinsic preferences as follows:

$$
U_{i}=\left(v\left(d_{i}\right)+\lambda\right) q_{i}
$$

Note that this formulation assumes that judges receive utility from their intrinsic preferences not merely by announcing them, but only by applying them in particular cases. That is, a judge gets no intrinsic utility from choosing a rule which is never applied, perhaps because the judge of the other court has chosen a more pro-plaintiff rule, so all cases go to the other court.

Proposition 2. If judges choose only strategies that are subgame perfect Nash equilibria:

(a) if $v\left(d_{i}\right)+\lambda>0$ for all $i>i^{*}$, then both courts choose the proplaintiff rule, that is, $d_{\mathrm{KB}}=d_{\mathrm{CP}}=d_{N}$.

(b) if $v\left(d_{i}\right)+\lambda<0$ for all $i$, then both courts choose the prodefendant rule, that is, $d_{i}=d_{j}=d_{1}$. 
(c) if $v\left(d_{i}\right)+\lambda$ is sometimes greater than zero and sometimes less than or equal to zero for $i>i^{*}$, then both courts choose $d_{\mathrm{i}}$ such that $v\left(d_{i}\right)+\lambda>0$ and $v(d j)+\lambda \leq 0$ for all $j>i$.

(d) if $v(d)$ is always increasing and $v\left(d_{\mathrm{N}}\right)+\lambda>0$, then both courts choose the pro-plaintiff rule, that is, $d_{\mathrm{KB}}=d_{\mathrm{CP}}=d_{N}$.

(e) if $v(d)$ is always increasing and $v\left(d_{N}\right)+\lambda=0$, then at least one court chooses the pro-plaintiff rule, that is, $d_{\mathrm{KB}}=d_{N}$ or $d_{\mathrm{CP}}=d_{N}$.

Proof. Because there are so many cases, a full proof would be very cumbersome, so I will give only the intuitions.

(a) If $v\left(d_{i}\right)+\lambda>0$ for all $i>i^{*}$, then both courts choose the proplaintiff rule, because if both courts choose the pro-plaintiff rule, they split a positive number of cases and receive some positive utility. On the other hand, if one court chose something other than the pro-plaintiff rule, the other court would choose a more pro-plaintiff rule, thus leaving the less proplaintiff court with no cases and zero utility.

(b) If $v\left(d_{i}\right)+\lambda<0$ for all $i$, then both courts choose the prodefendant rule, because by doing so, their utility is zero, because $q\left(d_{1}\right)=0$. On the other hand, if one court were to choose something other than the pro-defendant rule, its caseload would be positive, and its utility would therefore be negative.

(c) If $v\left(d_{i}\right)+\lambda$ is sometimes greater than zero and sometimes less than zero for all $i>i^{*}$, then if both courts have chosen the same decision standard, a move by one court one notch in the pro-plaintiff direction increases that court's judicial utility, as long as $v(d)+\lambda>0$, because it was assumed that if $v\left(d_{i}\right)$ $+\lambda>0$ and $v\left(d_{i+1}\right)+\lambda>0$, then $\left(v\left(d_{i+1}\right)+\lambda\right) q\left(d_{i+1}\right)>1 / 2\left(v\left(d_{i}\right)+\right.$ $\lambda) q\left(d_{i}\right)$. Thus, no pair of strategies is stable, as long as one court can choose a decision standard more pro-plaintiff than the other, as long as that more pro-plaintiff rule still satisfies $v(d)+\lambda>0$. So, the only equilibrium is for both courts to choose the most pro-plaintiff decision standard for which $v(d)+\lambda$ it is still positive. That is, the courts choose $d_{i}$ such that $v\left(d_{i}\right)+\lambda>0$ and $v\left(d_{\mathrm{j}}\right)+\lambda \leq 0$ for all $j>i$.

(d) If $v(d)$ is always increasing and $v\left(d_{N}\right)+\lambda>0$, then, for reasons similar to those pointed out in (c), the only equilibrium is for both courts to choose the most pro-plaintiff rule.

(e) If $v(d)$ is always increasing and $v\left(d_{N}\right)+\lambda=0$, that means that $v\left(d_{\mathrm{i}}\right)+\lambda<0$ for all $i<N$. That means judicial utility is negative, except at $d_{N}$, where it is zero. If one court chooses $d_{N}$, it 
receives zero utility, which is the most possible in the situation. On the other hand, if one court has chosen $d_{N}$, then it does not matter what the other court does, because it will get zero utility whether it chooses a different standard (in which case it gets no cases) or $d_{N}$ (in which case it will get half the cases, but its utility will still be zero, because $v\left(d_{N}\right)+\lambda=0$ ).

A corollary to Proposition 2 is that if fees are large and are taken away from judges, $\lambda$ will decrease significantly, and the decision standard will become more pro-defendant. This corollary justifies Prediction 1 above. Consider first the situation where initially $v(d)+\lambda>0$ for all $i>i^{*}$, and then fees are taken away and thus $\lambda$ decreases. If the decrease in $\lambda$ is large enough, it will now be true that $v(d)+\lambda$ is sometimes greater than zero and sometimes less than or equal to zero for all $i>i^{*}$. The shift will change the decision standard from the pro-plaintiff rule $-d_{N}$ as described in Proposition 2(a) - to a less pro-plaintiff standard (as described in Proposition 2(c)). If $\lambda$ continues to decrease, but $v(d)+\lambda$ is still sometimes greater than zero and sometimes less than or equal to zero for all $i>i^{*}$, then Proposition 2(c) predicts that if the change in $\lambda$ is sufficiently large, the decision standard will shift in a pro-defendant direction. If $\lambda$ decreases sufficiently, $v(d)+\lambda$ $<0$ for all $d$, and the decision standard will shift to the most pro-defendant rule (as described in Proposition 2(b)). Similarly, if $v(d)$ is always increasing and $v\left(d_{N}\right)+\lambda>0$, the courts will choose the most pro-plaintiff rule (as described in Proposition 2(d)). As $\lambda$ decreases, Propositions 2(e) and 2(b) predict that the decision standard will shift pro-defendant. 